movement for independence, significant, often unexpected, points of divergence and convergence crop up. Since local accounts draw their style from Bedouin cultura traditions and enhance its hero figures, the latter appear as a metonym for a group, and each group having its own account of events, Bedouin memory is pluralistic. It is segmented like the tribal society that has wrought it. Participation in the uprising, its leaders, the persons and events worthy of being remembered, all these points are symbolic issues and historical arguments brandished in debates about legitimacy. Since the memory of this uprising is closely linked to a more distant past, this local memory which is aristocratic, has remained indifferent to nationalistic themes and rhetoric. It celebrates a whole past rather than the founding event of a nation.

F. Pouillon - Colonial Legacy, National Heritage: Nasreddine Dinet, a Painter of Algerian Natives.

Independent Algeria's rehabilitation of a French " Orientalist " painter, who died in 1929, raises questions about how important the colonial heritage is in the making of Algerian identity. After examining the difficulties encountered in a biography that cannot be reduced to the interpretation of a spectacular conversion to Islam, facts are placed in their political and cultural contexts. Other figures, who have this legacy has been passed down.

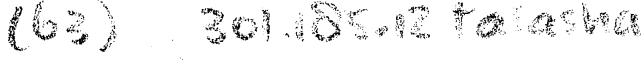

$$
\begin{aligned}
& 960: 3018 \mathrm{de}
\end{aligned}
$$

\section{The Enigma of Beta Esra'el Ethnogenesis. An Anthro-Historical Study*}

This essay is about the problem of the relation, between 'myths' and 'historical events'. The perennial question of how they interact will be treated with reference to a case study of an intriguing Ethiopian ethnic group: the Beta Esra'el or Falasha. ${ }^{1}$ These Ethiopian Jews have been the subject of a flood of international scholarly and journalistic publications, especially in the wake of their (initially secret) emigration movement from Ethiopia to Sudan to Israel (Parfitt 1985, Rapoport 1986, Safran 1987) This migration of Falasha refugees (which started about 1980) had first been severely criticized by the Ethiopian government. But shortly before his demise, even the former Ethiopian leader, Mengistu Haile Mariam, accepted the idea of their emigration, ${ }^{2}$ and a slow legal exodus, channeled through the reopened Israeli embassy in Addis Ababa, was organized. Most of the remaining Ethiopian Jews (ca. 14,000) have been flown to Israel just before the change of regime in Addis Ababa (May 1991). Thus, one of the most remarkable episodes of Jewish history, showing

* I wish to express my gratitude to the following informants in Israel: Qes Ishaq lyasu, Qes Imharen Ajjaw, Ato Admas Chekole, and the late Oes Birha For helpful and encouraging comments on preliminary versions of this text, am much indebted to Dr Steven Kaplan (Hebrew University, Jerusalem), to Professor Kay Kaufman Shelemay (New York University) and to Dr R. Schneide (Mission française d'archéologie, and Addis Ababa University). Of course, responsibility for the final result is mine alone.

1. In Ethiopia, the group called itself 'Bétä Esra'el' (the correct transcription of their Ethiopic name in Ge'ez or Amharic; the meaning is 'House of Israel'. They also called themselves 'Esra'élotch'(Israelites). In this text, I will use the simplified transcription Beta Esra'el. Ethiopian Christians and foreigners often called them 'Falasha', but they usually rejected the name, cf. ABBINK 1984a: 67, 1984b. In Israel, they prefer to simply call themselves 'Ethiopians' or 'Ethiopian Jews'

although one of their self-organization has taken the name of Bet Esra'el.

In an interview with the Israeli English newspaper Jerusalem Post (international ed., 10-17 Nov. 1990), Mengistu Haile Mariam, ironically, accepted the old theory that Judaism may have been the belief of the Northern Ethiopians before Christhe country in May 1991 the former Ethiopian leader, at that time hard for support from every corner, also appeared to subscribe to the earlier rejected "

Cahiers d'Études africaines, 120, XXX-4, 1990, pp. 397-449. 
a rare conflation of myth, legends, and modern political developments, is about to end. In fact, the Beta Esra'el community in Northern Ethiopia has ceased to exist, and the chapter of Ethiopian Jewry will soon be closed.

In Israel, the Beta Esra'el have been the subject of much public debate concerning the question of their 'religious status' as Jews (Abbink 1984b), that deemed to be important (in certain religious circles). This problem now appears to have been largely solved-as they have been supported by the Israeli government as legal immigrants under the Law of Return and are widely accepted as new citizens by the Israeli public in general. The majority of recent studies on the Beta Esra'el community (or now 'Ethiopian Jewish') in Israel is concerned with questions of their social integration and assimilation. ${ }^{3}$

As far as their history and culture in Ethiopia is concerned, many questions of course remain. It is perhaps surprising that there is as yet no comprehensive historical study on the Beta Esra'el. ${ }^{4}$ However, the (ethno-) history of the Beta Esra'el continues to hold the fascination of researchers, and the present study is a contribution to the analysis of the interplay of myth, legend, history and identity of the Beta Esra'el from a historical-anthropological perspective.

Among the Beta Esra'el in Israel, a process of 'recasting' or reformulating the history of their community in Ethiopia has been going on. This process - familiar from many ethnic groups undergoing rapid processes of change and therefore redefining their position and allegiance -shows aspects of myth-formation, often with an 'apologetic' character. In view of their somewhat precarious Jewish identity in the past (in the eyes of the above-mentioned religious authorities in Israel), an effort is made to retrospectively validate the Falasha traditions and religious ways, as well as their perseverance in the face of Christian assimilatory pressure of the past centuries. We can thus see a partial 'reinvention' of historical tradition.

In this study, chief attention will not be devoted to recent developments and problems of the Ethiopian Jewish community in Israel, but to an earlier phase of their history in Ethiopia: the issue of ethnogenesis, or origin history, and its mythical reflection in the ideological domain. The issue will be treated in a rather extensive fashion, in order to present all known variations or genres of the stories presented by the Beta Esra'el to a variety of travellers, researchers and other visitors. This will be done in conjunction with a view on the relevant historical knowledge available to date. The theoretical question guiding this effort is how one might

3. Cf. Abbink 1984a, 1984b, Dolève-Gandelam 1989, Goldberg \& KIRSCHENBAUM 1989, FRIEDMAN \& SANTAMARIA 1990, KAPLAN 1988.

4. E. TREVISAN SEMI's book (1987) only treats an episode in the 20th century. arrive at some historically plausible conclusions on the basis of a critical reflection of such mythical traditions.

While partly inspired by the structuralist approach to myth analysis, the concern of this article will be more with the relation of 'myths' with the praxis of their social production, in identifiable historical contexts. For the purpose of the discussion, mythical stories can be described as superstructural or ideological phenomena in narrative form which are present within a society and contain assertions on the origin of things and of humans and their position (specifically of the group to which the producers belong) in the cosmic and socio-historical whole.

In Christian Ethiopia, since the early Middle Ages, the mythical discourse, elaborated in a written corpus, has taken the form of historicist 'mytho-legends' of a religious nature. Their 'message' is tied to the Biblical ideas of divine plan and destiny, in a progressive time dimension.

In focussing on Beta Esra'el stories, my starting point is that they can only be seen in their proper perspective when related ideologically to the mythical tradition of the Amhara-Tigray. The Amhara and Tigray peoples ${ }^{5}$ were for a long time the two politically and culturally dominant groups in the region, especially during the time of the centralizing 'Solomonic' empire (established in ca. 1270 with King Yikunno 'Amlak, and abolished in 1975 after the deposition of Emperor Haile Sellasie). This empire conceived of itself as the legitimate heir of the old Aksumite empire and reaffirmed the dominance of the (Monophysite) Christian religion in the country. The Solomonic empire, with its base in the Northern Ethiopian highlands, developed an important literary tradition and an idea of historical mission of expansion.

The kind of myths which we will talk about actually consist of a kind of 'sacred narratives' (see Dundes 1984, Leach \& Aycock 1983: 8). We will use the new term mytho-legends, the logic of which will be explained below. The initial hypothesis will be that the Amhara-Tigray mytho-legends (especially the well-known Kibrä Nägäst, or 'Glory of the Kings', a medieval religio-political work, often designated as the national epic of the Christian Highlanders before the 1974 Revolution) and the Beta Esra'el mytho-legends on their own origin and religious tradition form part of one domain of discourse. The significant oppositions and transformations to be found in the one (Beta Esra'el) vis-à-vis the other (AmharaTigray) have been formed in an historical dialectic of power struggle,

5. The Tigray can be considered as a people closely related to the Amhara, linguistically, religiously and culturally (together they are often called Habesha, a term not applied to the dozens of other Ethiopian groups). They also saw themselves as carriers of the Christian heritage of the Aksum empire. Although the Tigray
often consider their language and traditions as quite different from those of the Amhara and often emphasize their own cultural-historical identity, I will consider both groups together as a kind of Christian Highlands unity, but I am aware of the profound rivalry between them. 
in which differences of ethno-religious identification emerged. The Beta Esra'el oral traditions, so far as they are known today, are largely reflections of this pre-existing written tradition of the Ethiopian Christian corpus and can only be understood in connection with the latter.

If we take this point of view, we cannot also but emphasize the role of historical myths as charters. At historically crucial junctures, the mytholegends can be utilized by certain groups as ideological mechanisms of defense and of justification, and as building blocks for self-identity or socio-political claims. They can provide meaning and ideological foundation for the group's existence. In dusting off this Malinowskian notion of myth as charter it is not implied that all mythological corpuses should only be judged in this sense and that the best theory of myth is a neofunctionalist one. But applying this viewpoint to the obviously historically informed mytho-legends of the Beta Esra'el may help to understand history proper.

The Beta Esra'el stories are stories about their origin and their 'descent', as well as about their religious affiliation and their position vis-àvis the ethnic groups which live around them. In combining the two words 'myth' and 'legend', I want to express the double nature of their stories. On the one hand, they refer to a 'sacred', a-temporal, and supra-empirical realm (taken from Biblical stories and traditions based on them), but on the other hand they carry quasi-historical references relating to specific events and episodes which have been processed in the way of 'legends', which always contain a grain of historical truth. But the legends are invariably placed in the divine, mythical scheme of things. We could define the mytho-legends as sacred narratives of a group, grounded in supraempirical notions (such as divine or spiritual forces) but carrying ideological functions and formulated in a historical-political arena, to articulate meaning for and 'destiny' of the group. Mytho-legends can thus be developed by a group as an ideological response to problems of the present, but refer to an atemporal dimension within which the group defines and legitimizes its existence.

Certainly the mytho-legends of the Beta Esra'el express a 'message' (for the group itself as well as for their neighbours). They provide a reinterpretation/reformulation of their own religio-historical tradition and of their own 'Israelite' lineage, which fuelled their resistance against the Christian Amhara-Tigray. The Beta Esra'el mytho-legends can be seen as variations on one theme: the tentative resolution of ideological contradictions which emerged in the wake of material (politico-economic) problems resulting from their defeat against the Amhara royal armies and from their forced incorporation into a Christian empire, the central values of which they rejected. Thus, the various stories and commentaries of the Beta Esra'el to be discussed here have undeniable historical referents, which should be assessed as far as possible. By analysing the stories in their political and cultural context, some more light can be shed on the problem of ethnogenesis of this remarkable group. As Leach (1969: 42-43), evaluating the problem of how to analyse chronological sequences of certain myths in a structuralist manner, has said:

'... the significance of individual items in any kind of story is to be found in their patterned arrangement. What attracts ... attention is not the content of any particular story but the contrast of pattern as between one story and another. The principle should be just as applicable to stories which purport to be "history" as to stories which are palpably "myth".

This can be literally applied to the Beta Esra'el mytho-legends. As we will see, the positioning of the 'individual items' in the various stories of the Beta Esra'el also yields significance for an understanding of questions of their ethnogenesis and self-presentation as a distinct group.

\section{The Beta Esra'el}

The Beta Esra'el are an Ethiopian ethnic group of about 35,000 to 40,000 persons, the majority of which now reside in Israel (ca. 34,000). ${ }^{6}$ Traditionally, the Beta Esra'el or 'Falasha' constituted one of the poorest and most despised group in North Ethiopian society. For many ages, including the reign of Haile Sellasie, they were deprived of the right to own land. They usually worked as tenant peasants on the lands of Amhara and Tigray farmers and landholders. They were share-croppers, giving the owners a large amount of the harvest as rent payment. They also provided corvée labour. Only in the Tigray region, where some Beta Esra'el groups settled during the 19th century, they were less restricted in their movements and could sometimes get title to land of their own. But the Falasha were especially known as the craftsmen of Northern Ethiopia: they did the blacksmithing, weaving, tanning, and pottery work. They were forced into these, locally disdained, occupations by their Amhara overlords in the 16th and 17th century (see below).

A core of Beta Esra'el has always maintained itself on the North Ethiopian Plateau, in spite of the fact that their Judaic religion was often

6. In 1976, a more or less reliable census was made by Mr Julian Kay working for a voluntary aid organization in Ethiopia. The number he arrived at was 28,189. Since the emigration of the Beta Esra'el through Sudan to Israel, the number of people declaring themselves 'Falasha' or 'Beta Esra'el' in Ethiopia has sharply risen. This is partly due to the fact that many former converts to the Ethiopian Orthodox Church (even of three or four generations ago) 'reconverted' to Judaism But also many Christian Ethiopians from the Gondär area come forward and say they are Falasha, because it brings them a chance to get out of Ethiopia North Ethiopia to Sudan: victims of hunger, disease and highway robbers. 
condemned and persecuted, especially in the period after their massive defeats in the 16th and 17th century against the royal Amhara armies. They were also frequently subjected to conversion campaigns, not only by the Christian kings but also by foreign missionaries, arriving in the first half of the 19th century. The number of Falasha has been reduced significantly in the last 400 years.

Since the 'rediscovery' of the Beta Esra'el by the Scottish explorerscientist James Bruce in the 1770's, historians, ethnologists, travel writers and religious dignitaries (from western Christian as well as Jewish background) have not stopped asking questions about their origins, history, and their specific form of Judaism (Kessler 1982, Abbink 1984b: ch. 2, 3). The Beta Esra'el have only been 'recognized' as Jews in a religious-ethnic sense since 1975 (a prerequisite to be accorded the automatic right to immigrate to Israel under the Law of Return), after a religious decision by a chief rabbi in Israel. Only after this date, a more serious immigration effort started, fuelled by actions of the small Falasha community in the country. ${ }^{7}$

Thus, the immigration efforts by the Israeli Government and by Jewish voluntary organizations have always been accompanied by debate on the status and identity of the Beta Esra'el, although at present (1990) the discussion seems to have been concluded. In itself, such a process of public discussion of the ethno-religious identity of a group, and the Beta Esra'el response and redefinition of their own identity, is a matter of great interest. It goes without saying that the group considers itself as an 'ancient Jewish community' with well-defined, time-honoured ethnoreligious identity. This is now a fact (although still not in all Orthodoxreligious circles in Israel). The Beta Esra'el or Ethiopian Jews in Israel appeal to Israeli-Jewish identity in a remarkable manner, and one cannot but recognize or respect their ardent wish to be considered as such. This stands in no direct relation to the continued scientific investigation of unresolved enigmas of their ethnogenesis and historical development, especially as reflected in some of their oral traditions.

If we turn to history, most researchers generally accept the idea that the Beta Esra'el are, at least in large part, of Agäw origin (the Agäw are the ancient 'Cushitic' population of the Ethiopian Highlands; some of their descendants still live there). It is also often assumed that the Beta Esra'el have a certain affinity with the ancient Israelites (although they probably never spoke the Hebrew language, nor were ever familiar with the Mishnaic and Talmudic traditions of post-Exilic Judaism, and, before the 19th century, never had any substantial direct contact with other Jewish communities in the world). But their beliefs and rituals, despite the strong basis in the Torah, were seen as very different from

7. In $1974-75$, only some 250 Falashas had lived in Israel. mainstream Judaism. It is also admitted that before the 15 th century there are no real clues to knowing what their society, beliefs, and ethno-religious affiliations looked like. All this has given much room for speculation and propagation of theories about where the 'Falasha' came from, not only by the interested public but also by most historians and theologians. ${ }^{8}$

One question is whether the Beta Esra'el-taking into account their Ethiopian-Agäw basis-have been led to adopt their Judaism from an external source, outside Ethiopia and the Ethiopian Orthodox Church ${ }^{9}$ or not. If we give a positive answer, then it must be assumed that the Beta Esra'el are the descendants of an ancient Judaic, Israelite community in Ethiopia, ${ }^{10}$ having at one point migrated to the Ethiopian coast from South Arabia, the Land of Israel or through Egypt.

Another possibility is to suggest that the Beta Esra'el have first and foremost been formed as a community in Ethiopia; possibly, but not demonstrably, influenced by early foreign Jewish visitors or migrant groups. They then would have been affected primarily by the rich but diverse Ethiopian Christian tradition, from which they took over and 'inversed' certain ideological elements to assert their own tradition, as a kind of oppositional movement. There are strong indications (and written sources for this) that groups, later to be called 'Falasha' or 'Beta Esra'el',11 were under strong influence of certain Christian dissident groups, which transmitted their symbolism and ideas of political opposition to native groups not yet incorporated in the Solomonic empire. Here, we are inclined to consider this second line of approach as the most promising. There still seem to be no convincing archaeological, literary, or historical data to plead for the first point of view. To check the second theory, a revaluation of known oral traditions of the Beta Esra'el is necessary. The most important points of departure for such a revaluation are the historical analyses of J. Quirin $(1977,1979)$ and the work of K. Shelemay on the liturgical music of the Beta Esra'el $(1980,1986)$. Their results suggest a close link between the Beta Esra'el and their immediate political, cultural and religious environment, i.e., the evolving and dynamic relation with the Christians. On the basis of their insights, a re-analysis of the structural position of the Beta Esra'el mytho-legends in the Ethiopian corpus as a whole can cast new light on questions of Beta Esra'el history.

8. Cf. KAPLAN \& BEN DOR (1987) whose bibliography contains most of the references.

9. The Ethiopian Orthodox Church has, since its foundation in the 4th century C.E. retained a large amount of Judaic elements, cf. RODINSON 1964; also ULLENDORF 1968 .

10. The word 'Ethiopia', as a name for the country, was mentioned in the Kibrä Nägäst. 11. It is very doubtful that they already called themselves 'Beta Esra'el' before the arrival of these Christian apostates or failed reformers, unless we associate them with the followers of the so-called brother (and rival) of the 9th century king, Gäbrä Mäsqäl (GETATCHEW 1982: 319). But then they would certainly have been of Christian origin. 
One important reason for considering the Beta Esra'el material in its dialectic ideological relationship wih the Amhara-Tigray mytho-legends is that the former never does directly refer to a non-Ethiopian tradition, i.e., to material not written in Ge'ez (the medieval Ethiopian religious language) or transmitted through non-Ge'ez (or non-Amharic, nonTigrinya, non-Agäw) channels, nor to myths and legends known in those languages.

\section{The Ethiopian Context: The Amhara-Tigray and their Mytho-Legends}

At the time that the Beta Esra'el-Falasha are identifiable as a distinct ethnic group in Ethiopian history, i.e., after 1400 (Quirin 1977: 34), the 'Solomonic' empire of the Amhara was already well established in the Northern Highlands. Since 1270 the Amhara king Yikunno 'Amlak was king of a new, self-conscious royal house. Power had been wrested from king Yitbaräk, the last scion of the Zagwe dynasty in the Lasta (Wällo) region. These Zagwe were Christians, but of Agäw origin and had been resented by the Amhara-Tigray, because they were not seen by them as the legitimate heirs of the Aksumite empire. The Solomonids reinstated the Aksumite mythos of Israelite descent of the Ethiopian kings. It is important to note that the Beta Esra'el mytho-legends seem to have been conceived in the context of the new Solomonic empire, founded after the Zagwe (whose reign in Ethiopia was actually only an interlude of some 120 years). They do not seem to be formulated before the 15th century, as we will see below. Before explaining the importance of the Zagwe/Amhara opposition in the politico-ideological domain, a few words must be said on the historical background.

\section{The Pre-Solomonic Historical Context}

When the ancient empire of Aksum was establishing its ideological base, it already appealed to Biblical traditions, a basis which could ground the authority of kings in divine right. The well-known Aksumite inscriptions on the royal stelae confirm this: they speak of Aksum as being the 'new Zion'. Certainly, Aksum considered itself a legitimate successor state of Ancient Israel as far as 'divine' kingship is concerned, certainly at the time of king Caleb (ca. 520-540). Shahîd (1976) has said that the Kibrä Nägäst, known to us in its final 13th century version, was probably in its original form a creation of the 6th century (being a reflection of the war between Aksum and Himyar under the Judaic king Yusuf Dhu Nawas). If this is true, then the religious-ideological conflict between Christian and Judaic traditions as styled in the Kibrä Nägäst refers indeed directly to the Jewish or Judaized king of Himyar, and not to any Ethiopian king or party (this is not entirely clear from the text itself).

It has to be added here that the question of whether one can already speak of a definite 'Solomonic' dynasty existing in the 4th century and after cannot be answered definitively. We neither reject or accept the thesis that the idea of the Aksumite kings having descended from the son of the Queen of Saba/Sheba and King Solomon (see below) was only retrospectively declared as state myth, i.e., after the foundation of the Solomonic monarchy of 1270. However, Shahîd (1976: 158-159) has shown that there is at least a possibility that king Caleb, the central protagonist of the Kibrä Nägäst, already called himself a descendant of this line.

The existence of Jewish communities in the Aksumite empire in this period cannot be demonstrated. If they were there, they have not left any traces in language, writing or architecture, although it is true that many legends, stories and religious ideas of Jewish origin penetrated the kingdom (but again, this also holds for Greek, Arab and Syrian ideas of the same period). According to our knowledge, it is probable that most ideas were transmitted by way of the Ethiopian Christian Tradition, which absorbed so much of the Near Eastern written sources (especially Egyptian and Syriac).

\section{The Solomonic Empire and the Menilek Myth}

It is necessary to underline the fact that this new monarchy defined itself specifically as the legitimate 'Israelite' lineage of the Ethiopian kings. The Zagwe had been considered as 'usurpers' of the royal line. Next to the political factor, the importance of an underlying ethnic factor is important here, but this point cannot be elaborated here. Still, a consideration of the Kibrä Nägäst and subsequent religious tracts and oral commentaries should be viewed against this background.

This brings us to the reign of 'Amdä Siyon (1314-1344). Under this monarch, the ninth in the dynasty, a final version of the Kibrä Nägäst was made. It was edited by representatives of the Tigrinya clergy, ${ }^{12}$ but, as we saw, following Shahîd (1976), on the basis of an already extant version. Under the new Solomonic dynasty the text was reworked and used more emphatically as a politico-ideological charter. In the Kibrä

12. A plan of this work is given by LEVINE (1974: 94). It must be noted that SHAHÎD (1976) appears not to attach much importance to the moment of final editing duced, by whom and for what reasons? 
Nägäst we find the well-known founding myth of the Amhara-Tigray royal house and people. It describes them as the new people elected by God. As we can read in the following text: 'Zion [meaning the original Ark of the Covenant, JA] aber hat seinen Wohnsitz bei Deinen Erstgeborenen genommen und wird zur ewigen Erlösung des Volkes Athiopiens werden ...' (Bezold 1905: 67).

The Kibrä Nägäst thus contains the historico-religious charter of the new Christian dynasty, which saw itself directly favoured by the Grace of God. Although the work consists of several strands of myth, taken from different sources and cycles, we will only take up the principal mytholegend concerning the descent of the Amhara-Tigray and their kings, which can be summarized as follows (ibid. : 134). After the death of her father (an important chief of Tigray origin), Makeda had
become queen of Saba (located in Ethiopian territory). Her father had, with magical become queen of Saba (located in Ethiopian territory). Her father had, with magical means, defeated the Serpent, which had reigned in the country for 400 years. Makeda,
a virgin queen, was a follower of the religion of the Sun. A trader one day told her of the boundless wisdom of Solomon, king of the Israelites. She decided to visit him in Jerusalem. Solomon received her well and she was delighted. After many long conversations with him, she was inclined to accept the monotheist religion of her host and '. . . no longer adore the Sun, but the Creator of the Sun'. Before she returned to Ethiopia, she dined with Solomon and agreed to pass the night in his rooms in the palace, although she refused to sleep with him. Solomon promised he not to seduce her, but on condition that she would not forcefully take anything that wich heavilyspiced dinner, she drank water without asking Solomon. He saw her and reminded her of her promise. She was obliged to sleep with him. Having returned to Ethiopia Makeda, after nine months, gave birth to a son, whom she called Menilek [in some versions, Ebna Hakim or David].

When Menilek was a young man, he, in his turn, visited Solomon to complete his education. In due time he was to return to Ethiopia. Solomon, wishing to establish the faith more solidly in Ethiopia, chose a select group of men, 'first born' of notables and priests, to accompany him. At the instigation of Azariah, the son of High Priest Zadok, a copy of the original Ark of the Covenant was made. This copy was surreptitiously placed in the Temple, while the original was stolen to be tal we taken to Ethiopia. Menilek and his company took leave of Solomon and aroused no suspicion. Menilek only heard of the theft while the company was well on its way back, but he approved of it. Solomon's men, after the theft was discovered, could not retrieve the stolen Ark, because God protected Menilek. Upon arrival in Ethiopia, the Ark was placed in a sanctuary in Aksum. Since then, Aksum is the new Zion, protected by God, and the Ethiopian Kings were after that considered as the guardians of the Ark, with a divine mission for the country. The divine glory was thus transferred from the Israelites to the Ethiopians: the Israelites were now discredited. Menile became the first king of a new dynasty and all true monarchs of the country descend from him. And no queen would ever be allowed to govern Ethiopia. The status of New Elects was confirmed by the arrival of Christianity in the country, as foretold New the prophesies of the Old Testament. Thus Ethiopia '... would continu guardian of the Orthodox faith until the arrival of the Lord'.

In the last chapter of the Kibrä Nägäst, battles with the Jews are foreseen. The Jews are presented here as a people which has been rejected and vanquished. According to some supplementary stories from the Ethiopian tradition (cf. Krempel 1972: 23, 26-27), Makeda, when returning from Israel, was accompanied by a group of artisans and builders: the ancestors of the 'Falasha'-inferior to the Amhara-Tigray because they did not descend from the group of first-born.

The Kibrä Nägäst, especially this myth of Menilek and the purloining of the $\mathrm{Ark}^{13}$, has been the subject of a great number of interesting interpretations (see Levine 1975, Spencer 1979). Instead, the Menilek myth will be taken as a point of departure, as the ideological basis, the historicist framework of the Solomonic state, cherished as its charter for royal authority and expansionist aims in the entire Ethiopian region, extending far into the south, beyond the former Aksum area. Such an interpretation of the Kibrä Nägäst (there are other interpretations possible at the same time) does not detract from the earlier mentioned theory that this epic, in its main outlines, was already composed in the 6th century. Nor does it deny the use of this text (edited by Tigray clerics) by non-Amhara groups for religious-ideological ends, opposing the Amhara-expansion.

The myth was part of the sacred narrative of the Solomonic royal house and seen as real history and eternal truth (until 1974). We may note at once that it does not (like most tribal myths) present any cosmological dimension except by implication (through the Old Testament stories). It is a narrative relating certain episodes in the life of mytho-legendary persons and relating to identifiable societies and their relative position in terms of prestige. The hand of God is recognized as the active principle in the history and destiny of Ethiopia, emphasizing the historical vocation of the Christian Amhara-Tigray. This mytho-legend could obviously be used to legitimize their practice of domination and expansion, which was becoming so evident for the non-Amhara peoples in the course of the conquests.

We have already expressed our doubts concerning the existence of the 'Beta Esra'el' as a well-delineated Jewish ethno-religious group, before the great wars of the period 1390-1415 between their ancestors and the Amhara. In this respect, the narratives of various travellers (like Eldad haDani, 9th century) and Binyamin of Tudela (12th century) are not sufficiently solid as historical sources. Furthermore, the oral tradition of the Beta Esra'el shows a significant breach: it can be said to refer to two distinct periods, i.e., those before and after ca. 1400. The narratives referring to these two periods have a remarkably different character in style and themes. This fact is much more important than is commonly recognized. The pre-1400 episode which is treated in their mytho-legends

13. In the eyes of the Ethiopian Christians, this episode granted an especially strong claim to their own faith and gave an additional reason to retain the Old Testament Judaic traditions in their Church which was seen as the guardian of the words and commandments of God. 
bears a more mythical stamp, while stories relating to the post-1400 period usually refer to events and developments which have an historical ring. They are, so to speak, more legendary than mythical. There is a reason for this. It is precisely this qualitative difference which leads us to fruitfully reconsider questions of ethnogenesis and historical development. To be able to do this, first some more has to be said on the socio-political context of the Beta Esra'el in the medieval and early modern era.

\section{The Social Position of the Beta Esra'el since the End of the 14th Century}

On the basis of oral and written sources it is incontestable that, after the beginning of the 15th century, a Judaic group of Agäw origin (they spoke an Agäw dialect until well into the 19th century) lived in a region at the margins of the Solomonic empire. These people, who might be called the 'proto-Beta Esra'el',14 had their own religious and political chiefs (later often called 'kings' in the literature) and lived in a noncentralized society. They were not subjects of the Amhara kings, but some of them may have paid the usual tributes to the latter (Quirin 1977: 52). This was common for the smaller states or principalities bordering the empire (e.g., the eastern Muslim chiefdoms). However, since the reign of the great warrior-emperor 'Amdä Siyon (1314-1344), the proto-Beta Esra'el were considered as an increasing danger for the empire, because they revolted against the continuing political and religious expansion of the Christians and against their pretension of carrying out a divine mission of conquest. Although it is probable that the proto-Beta Esra'el were already 'evangelized' extensively, 15 it is impossible to give an outline of the kind of society and religious culture they had at that time. Their oral tradition does not contain any information on this point; at the most, it suggests an incipient process of erosion or modification of the Agäw basis of their culture.

But the most crucial point is the following: exactly in this period, the late 14th and early 15th century, the proto-Beta Esra'el were

14. It seems that in the period before ca. 1400, neither the name 'Beta Esra'el nor the name 'Falasha' was used by the Ethiopians for the Ethiopian Jews. Study of the Beta Esra'el oral tradition itself does not permit any conclusions regarding the date or reason of its adoption (Cf. supra fn. 9). James BRUCE (1830-32, IV: 211) made the interesting remark that the name Beta Esra'el ('House of Israel') 'House of Judah', from which David, Manilek and the Solomonid kings had descended.

15. Significantly, in the royal chronicle of king 'Amdä Siyon, the rebels in the north were designated as renegades, 'former Christians' who had become 'like the Jews', see KREMPEL 1972: 34-35, QUIRIN 1977: 53. profoundly influenced by Christian 'dissidents' leaving the institutional fold of the Ethiopian Orthodox Church: monks or 'holy men' (Kaplan 1984: 42, 65-66, 102; 1985b) They left the Church because of certain doctrinal differences and because of their vehement criticisms of policy and behaviour of certain Solomonic kings (Krempel 1972: 35, Kaplan 1984: 36-37). According to several authors (Quirin 1977; Shelemay 1980, 1982; Kaplan 1984) these dissidents would have had a considerable influence on the way of life and religious identification of the people who came to be called Beta Esra'el (see below).

For the moment, returning to the theme of the relationship between them and the Amhara, particularly under the kings Dawit (1380-1412) and Yishaq (1413-1430), 16 the Beta Esra'el-Falasha were obliged to defend themselves against the royal armies. A long period of wars starting with the reign of Dawit only ended in 1625 with the complete submission of the Beta Esra'el under king Susenyos (1605-1632) (Quirin 1977: 76). During this period, they were in the process of losing their territorial autonomy and their economic base. King Yishaq especially played a decisive role in this (ibid.: $54 s q$.), although also under Särts'ä Dingil (1563-1597) there was heavy fighting. Throughout the ages, the Beta Esra'el were formidable opponents of the Amhara kings, as is evident from the latters' chronicles (Hess 1969).

Although it is now difficult to assume that the designation 'Falasha'17 was introduced in the early 15 th century by king Yishaq, it seems that this term was since then exclusively associated with Judaic rebels. We know the famous decree allegedly issued by Yishaq after the start of his military expedition against the 'Beta Esra'el' of the Wägära region in the years 1414-1415 (see Taddesse 1972: 201): 'He who has been baptized in the Christian faith may inherit the land of his father; otherwise, let him be a fälasi.' Apparently, the word fälasi here has the meaning of 'person without rights to possess land', 'temporary resident', or 'visitor'. There is a more literal translation: 'wanderer', which leads to 'emigrant', 'exiled'; another meaning is 'proselyte'. ${ }^{18}$

But today it is certain that the decree was only drafted and published well after Yishaq's reign (Kaplan 1985a). Therefore, the qualification 'falasha' or 'fälasa' initially may have been quite widespread, referring to several groups, not only to the Judaized ones. It is thus impossible

16. And possibly under Säyfä 'Ar'äd (1344-1371), see QUIRIN 1977: 52, 60

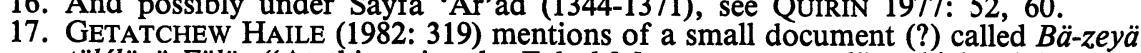
täléläyä Fäläs ('At this point the Falash[a] were separated'), which might refer to the 9th century episode of the refusal of certain Christians in the Aksum empire to the 9ccept the religious reforms of king Gäbrä Mäsqäl.

18. Cf. SHELEMAY (1977: 246), following Dillmann, also gives 'hermit', i.e man separated from others, and KREMPEL (1972: 257) gives 'hermit', i.e. man 'uprooted ' or 'cut off'. All this explains the pejorative meaning of the word: it designated a group of wanderers and 'rootless' people without a home area. 
to say whether the proto-Beta Esra'el, before they were termed 'Falasha', already called themselves 'Beta Esra'el'.

After the final campaigns of the year 1625 (at that time there is no longer any problem of identification), the Beta Esra'el lost all semblance of political autonomy. All remaining rights to land were taken from them; Amhara (including their many churches) became landowners (with inheritable gult fief-holding rights) and also immigrated to their area. The Beta Esra'el were more and more forced to take up low-status artisan work and became a 'declassed' social group, strictly speaking a kind of appendix of the Amhara quasi-feudal order (Abbink 1987). This is the reason why many of them dispersed over a large area of Northern Ethiopia and Shäwa. They were also under constant assimilatory pressure from the dominant group, although the forced conversion campaigns ended after king Susenyos. But the presence of the Beta Esra'el on Ethiopian soil was hardly seen as legitimate: they were now a wandering group, living on sufferance of the Christians. There was an injunction that they could not cultivate their lands and had to leave a certain place after two or three generations in order not to strike roots.

This attitude of the Amhara-Tigray was reinforced and defended with reference to myths like those in the Kibrä Nägäst, which had designated the Jews (in its last chapters 95 to 117), as a vanquished people, degraded and eternally subjected. The politico-economic and ethno-religious difference between the two peoples was also laid down in taboos on intimate social contacts, on food and eating habits, and reinforced by supernatural representations (the attribution of dangerous magical power to the Falasha). Although the rigid attitude of the two groups toward each other (the Beta Esra'el developed their own code of behaviour) was relaxed a bit during the ages (they also knew long periods of peace and symbiosis), a significant social and religious cleavage persisted, and mutual suspicions resurfaced at critical moments, well into the 20th century (cf. Kessler 1982: 151).

In sum, the military and political defeat of the Beta Esra'el and their socio-economic 'declassing' provoked a kind of 'delegitimization' of their own political and religious identity in the context of Abyssinian society. Their marginalized position was felt as humiliating and unjust. It is in response to this enforced social position in Northwest Ethiopian society and their being 'inferiorized' that they presented another reading of history and of the dominant mytho-legends. They modified key elements in these traditions in order to ideologically deny the Amhara-Tigray versions and to present a counter-model.

\section{Mytho-Legends of the Beta Esra'el}

Of the two periods represented in the mytho-legendary thought of the Beta Esra'el, the first one will be tackled first. In the following pages, we will establish that the mytho-legends of this first (pre-1400) period are essentially variations of the Amhara-Tigray-Christian version presented above. When we have found something of their meaning, we will move towards a consideration of the stories of the second (post-1400) period, which show a clear reduction of the 'mythical' element proper in favour of the legendary, more historical aspect. From an historical point of view, the riddle of Beta Esra'el ethnogenesis, as stated at the beginning of this study, is exactly situated on the breakline of these two periods.

The known Beta Esra'el versions of the Ethiopian mytho-legends often take as their basis the Menilek myth. They do not constitute an autonomous tradition transmitted over the ages within their own community since the assumed migration from Israel to Ethiopian shores. (There is no evidence yet to substantiate such a migration, not even of small groups.)

One of the old priests of the Beta Esra'el in Israel even told me that the Kibrä Nägäst contained the essential origin story not only of the Amhara but also of the Beta Esra'el. This may perhaps look strange, but, as we will see, in a certain fashion he was right.19

The stories of the Beta Esra'el appear to consist of secondary elaborations on a basic theme and to have been composed later than the Christian versions. They often seem to bear the stamp of being a response to the problems evoked by the 'official' version of the Menilek myths (and often they literally were, in response to question of white visitors). The reason is that the dominant version evidently carried the implication that the Beta Esra'el Jews were not only in the wrong religiously speaking, but were also denied rights on Ethiopian soil.

19. His remark and the reading of the fascinating article by SHAHID (1976) make it seem possible that my informant, Qes Birhan, one of the last products of the monastic education system of the Beta Esra'el religious leaders, may have been completely right. Consider, for example, the conquest of Judaic Himyar ay the alled subsequar noble to Ethiopia by the Beta Era'el (in their or Yusuf Dha Nawas as Pinchas Zoanush name 'Beta Esra'el' by the Falal thadion), and the possible adoption of the of on of the tho Mäsqäl altho sons of king Caleb (Beta Esra'el, the other one being Gabra material for the interpretation of this intriguing episode. A Ethis offers new the possibility that the Beta Erra'el, in their role as political rebels, saw them selves as the descendants of this group of exiled pimyarites. Compare the remarks by James BRUCE (supra fn of exiled Himyarites. Compare also obvious that the interaction between 'Christians' and 'Jews' in $1 . b$. It seems a much more complex and longer process of development than is commonly thought. 
The Beta Israel Versions Concerning the First Period:

The Theme of their Origin and their Belief

There is a certain (fairly limited) number of mytho-legendary sources, yielding different versions. On the basis of the regional provenance of the narrators, one may often note a difference of emphasis and of time structure in the stories. There is no central, 'normative' version. From the Beta Esra'el point of view, one may distinguish three strands of mytholegend, of which the third one is the least important.

1. The dominant tradition (and the one most widely accepted among the Beta Esra'el up to the 20th century) was the one derived from the Menilek myth. Presenting versions of this type 1 vis-à-vis the Amhara-Tigray and curious foreigners, the Beta Esra'el expressed their wish to be regarded, not necessarily as descendants of king Solomon, but as the contemporaries of Solomon and Menilek, originating from the kingdom of Israel. Some examples of this type will be treated in more detail below.

2. The second tradition underlines the 'Egyptian route', directly inspired by the Biblical myth of the Exodus of the people of Israel, or relates to the flight of the Jews into Egypt after the destruction of the First Temple in Jerusalem, in 586 B.C.E. The forefathers of the Falasha are here supposed to have arrived in Ethiopia coming from the North, independently from Menilek and his company. The versions most frequently presented were the following:

2.a

'Zur Zeit der Emigration aus gypten stritt ein Teil der Israeliten mit Moses Gber den Weg und die Richtung in das gelobte Land. Die streitende Partei wandte sich von der allgemeinen Menge ab und ging eigene Wege. Nach langen Wanderungen erreichten diese Israeliten das Hochland von Abessinien, wo sie sich niederliessen, erreichten diese Israeliten das Hochland von Abessinien, wo sie sich niederliessen, Hauser baute 24 ).

('At the time of the emigration from Egypt, one section of the Israelites argued with Moses about the right way and direction to the Promised land. The contesting party turned away from the general crowd and went its own way. After long wanderings these Israelites reached the highlands of Abyssinia where they settled, built houses, cultivated fields and remained loyal to the faith of the fathers.' Translation is mine, JA]).

A different version (2.b) of the Egyptian route has been given by the Protestant missionary J.M. Flad (1869: 4). According to his report, the Falasha said that:

6. . . ihre Vorväter als Flüchtlinge von der assyrischen bis zur babylonischen Gefangenschaft nach gypten entkamen, von da Nilaufwerts gingen um sich im westlichen Teil von Abessinien, in der Provinz Quara niederliessen.
Von dort aus hatten sie sich wahrend der letzten Jahrhunderte auch in die Provinzen Dembea, Wogera, Semien, \&c. verbreitet'.

('. . their ancestors, as refugees from the periods of the Assyrian and Babylonian exile, escaped to Egypt from where they went upwards along the Nile to settle finally in the western part of Abyssinia, in the province of Quara. From there they finally in the western part of Abyssinia, in the province of Quara. From there they
were said to have dispersed also to the province of Dembea, Wogera, Semien, etc., were said to have dispersed also to the province of Dembea,
during the last few centuries.' [Translation is mine, JA]).

This version can be considered as a pure legend, without any specific 'mythical' ingredients, and therefore we will not elaborate upon it.

A third version (2.c) is the following:

'Jeremias floh mit einer grossen Zahl von Flüchtlingen vor Nebukadnezar nach Ägypten. Vielen Flüchtlingen wurde ein Aufenthalt in Agypten verboten, sodass eine lange Zeit der Wanderungen begann. Vorübergehend siedelten sich die Flüchtlinge in Oberägypten an, doch auch von dort wurden die Israeliten vertrieben. Abessinien war der letzte Zufluchtsort' (Krempel 1972: 25).

('Together with a large number of refugees fearing Nebukadnezar, Jeremiah the prophet] fled to Egypt. Many refugees were denied their stay in Egypt, so that a long period of wanderings began. The refugees temporarily settled in Upper Egypt, long period of wanderings began. The refugees temporarily settled in Upper Egypt,
but also from there the Israelites were chased out. Abyssinia was the last even.' [Transbut also from there the
lation is mine, JA]).

Yet another, rather unknown version (2.d) (Flad 1869: 4-5), says that the 'Falasha' were only chased from Judea to Ethiopia after the destruction of the (Second) Temple in Jerusalem by the Romans (in the 1st century C.E.).

These mytho-legends all seem to be derived from the written Abyssinian tradition and from the (Ge'ez) Bible. In interpreting these stories, first the difference should be noted between $2 . a$ on the one hand, and 2.b, 2.c, and 2.d on the other, from the temporal point of view: $2 . a$ is situated before the episode of Menilek, while the others are situated after it. Of these type 2 versions, $2 . a$ was probably (together with $2 . e$ ) the most widely accepted version among the Beta Esra'el, judging from the literature and informants' responses known to us.

Finally, a very important version, also emphasizing the descent of the Beta Esra'el-Falasha from the refugee Israelites (here, notably, from Judea, 6th century B.C.E., and not from Israel, the Northern.kingdom!) was told by an old and respected High Priest of the Beta Esra'el (Schoenberger 1975: 11-14); I present it here in its entirety, because Schoenberger's study has not been published):

2.e

'The Falashas migrated like many of the other sons of Israel to exile in Egypt after the destruction of the First Temple by the Assyrians in $586 \mathrm{BCE}$ (the time of the Babylonian exile). This group of people was led by the great priest, On. They remained in exile in Egypt for a few hundred years until the reign of Cleopatra. When she was engaged in war against Augustus Caesar, the Jews supported her. When 
she was defeated, it became dangerous for the small minorities to remain in Egypt and so there was another migration (approximately between 39-31 BCE). Some of went to South Arabia and further to the Yemen. Some of them went to the Sudan and to Soun guided them through the desert. Some of the the Sudanese border), and some came via Eritrea. The settlement of the Falashas in Ethiopia was prior to the settlement of the Amharas, the Tigrinyans, not to speak of the Gallas. At this time, Ethiopia was populated by indigenous peoples-the Agau (Cushitic tribes) and partly by Semitic Arabian tribes. The population at this time was ignorant of any handicrafts or technology. This made it a very convenient place for the Falashas to settle, for they had come from a civilisation in Egypt with a knowledge of craftsmanship such as building, smithing, weaving and potting. With their knowledge of these crafts, they became the uncrowned governors of the area. They were able to influence the native population and brought about many changes. They Falashas and the loca population, which brought about the possibilities of intermarriage, which is why we have dark skins. In some areas, till today, there are Falashas who speak the language of the original inhabitants and because most of the Jewish immigrants were men, and because there were few Jewish women, there were mixed marriages with the Agau people and that is how the Agau language was passed to the Falashas. From this time until today, we have called ourselves Beta Israel. The Falashas had seven kings, all of whom were named Gideon, and one queen, named Judith. King Gideon I was the king of Beta Israel at the time of Abyssinian king Barzil, who governed in Eritrea when Gideon I ruled in Axum. At this time, there were friendly relations between the two kings. Later in time, there was an Abyssinian king named Kaleb, who wished and conquered it. And so, during his reign, there came another group of Jews to Ethiopia, led by Azono and Phinhas. They became famous as Jewish missionaries and had a lot of succes in converting the pagan Agau to Judaism. And this, [. . . ] is also the time when Judaic elements first infiltrated into the teachings of Coptic Christianity. After the reign of four Gideons, Judith ruled. She was the daughter of Gideon IV, and it is known that she ruled in the tenth century for forty years. She rebelled against the Christian Amharas because they threatened the Falashas by trying to convert them to Christianity, and for this reason she burnt many Christian churches and killed a lot of priests, and in fact, threatened the entire Abyssinian empire. Finally she was defeated because it was not enough for her to fight only against the Christians, but she also began to fight against Arab to fight against Arab tribes who had begun to infiltrate ino her kingdom through Eritrea. For a long time after Queen Judith the this time, the Falashas fought a lot of wars against the Christians who oppressed them as a revenge for the deeds of Judith. Then came Gideon V who reorganized the Falashas to fight against the Christian domination. Then there was Gideon VI, and then Gideon VII, who was also known as Gideon Falasha. He was the last of the Falasha kings. He reigned during the time of the Abyssinian king Isaac, during the fifteenth century. During this time there was a big war between the two kings which resulted in the defeat and the oppression of the Falashas forever. When Gideon VII was killed in battle, the power of the Falashas was broken at the centre. There was no one to take his place as a leader and no one strong enough to reorganize the Falasha defences, is ping Isaac scatered the Falashas by force all through Begemdir to small villages. so king Isaac scattered the Falashas by force all through Begemdir to small villages. He was the one who took the privilege of title to land from us. It was at that tim ' it also means that it is someone who is not allowed to own land.'

This story was not taken verbatim from the informant (Qes Birhan), but reconstructed by Schoenberger on the basis of the responses she received. Again, we see here a kind of pseudo-history or legend, rather than a 'myth' proper. It offers a fairly complete synthesis of nearly all elements of myth and history known among the Beta Esra'el at the point (1973). One recognizes ideas from the Kibrä Nägäst, from the Bible and from Agäw traditions, and as such the story offers a number of possible historical interpretations, none of which can yet be corroborated by evidence from other sources (For instance, the tradition of the Gideon kings before Aksumite king Caleb). When this version was presented, the idea of an eventual emigration to Israel by the Falasha was becoming a very popular issue in the Beta Esra'el community and in Israel itself, and the need to show that the Falasha were 'Jews like any others' was becoming urgent.

This story 2.e thus shows an intelligent combination of diverse legendary and historical elements (partly derived from modern historiography) which are often somewhat contradictory. Its fundamental idea is that of the movement of the Jewish Beta Esra'el through space and time, who, from the moment of their exile from Judea, participate in all the important historical events in the region, among them: the flight of the Jews after the destruction of the Temple (a biblical story); the emigration to Egypt and to Yemen, and from there to Ethiopia; their arrival in Ethiopia before that of the later dominant groups; the problems with Aksumite king Caleb and the expedition to Yemen; the religious conflict with Christianity and Islam (the Arabs); the big conflict with warrior-king Yishaq. It is also evident that certain characteristics of the Beta Esra'el as an inferior quasi-caste are projected back into the past, and at the same time 'inverted'-although they were despised by the Christian Abyssinians because of their craftsmanship, in the past this had given them a certain measure of status and power-their cultural affinity with the Agäw is explained, and indeed the revolt of the Agäw under Queen 'Gudit' (or 'Yudit') is reinterpreted as a Jewish revolt.

For reasons of internal inconsistency, it is impossible to accept this story as an ancient or traditional version of orally transmitted mytholegend on the origin and early history of the Beta Esra'el: fifty years ago, for example, such a story would never have been told. It is more of a modern bricolage, as it has never been presented in this form by any other informant. We see here again that myth and mytho-legends reflect the concerns of a group in a particular period and are constantly adapted and changed.

3. In addition to these two traditions, a third one can be distinguished. It is connected to a Jewish Orthodox interpretation, which was probably first stated by a 16th-century rabbinic authority, Rabbi David ibn Abu Zimrah, but taken up by the Sephardi Chief Rabbi in Israel. In 1972, he issued a psak-din (a kind of authoritative rabbinical decision), saying that the 'Falasha' were Jews who had descended from the tribe of Dan, 
one of the 'Ten Lost Tribes' of the kingdom of Israel (destroyed by the Assyrians in the 8th century B.C.E.). ${ }^{20}$ Schoenberger remarked (1975: 14) that the High Priest cited was aware of the discussions in Israel on the 'religious status' of the Beta Esra'el and also referred to the idea that the Beta Esra'el were Danites, although this would be somewhat contradictory with the narrative 2.e just cited, and must be considered another innovation. ${ }^{21}$

\section{The Solomonic Versions}

We now present some variants of type 1 narratives, in order to be able to elaborate our hypothesis later. Together with the ones mentioned, these versions were the most popular or current ones, often presented to AmharaTigray and foreign visitors before the 20th century. What do they tell us, compared with those of the Amhara-Tigray?

The first version (1.a) has been recorded by James Bruce (1830-1832, IV: 208-211):

'Reconnaissant la même tradition à propos de Salomon, de la reine de Sheba et de Ménilek, les Falachas disent qu'ils sont les descendants des juifs qui accompagnèrent Ménilek de Jérusalem en Éthiopie. Ils sont restés fidèles à la foi Israélite de Salomon et de la reine de Sheba, même au temps de "l'apostasie", sous les rois Abräha e Atsbäha.22 Â ce moment-là, les Falachas choisirent un nouveau souverain de la tribu de Juda, de la ligne de Salomon et Ménilek, nommé Phinéas. Tous les souverains falachas qui suivirent descendent de lui'.

As we already mentioned (fn. 14), Bruce says that the name of 'Beta Esra'el' was given to them by the Abyssinians to distinguish them from

20. Dr Steven Kaplan (Hebrew University, Jerusalem) has referred me to the report of Elijah of Ferrara of 1438 (YA'ARI 1971). I have not been able to consult this source, but Dr Kaplan told me what follows: Elijah, having encountered an Ethiopian Jew in Egypt, notes that the Ethiopian Jews called themselves members of the Tribes of is not des, and in the is not described in the

me recent narrative innovations in the mytho-legendary tradition of the Beta Esra'el, we will not treat them here, because despite the differences in detail and emphasis, the substance is often the same. (Usually, the number of stories presented now is much reduced.) Such innovations or adaptations also occurred in other spheres: see S

22. The 'apostasy' is the conversion to Christianity in the 4th century. According to the tradition, Abräha and Atsbäha were the kings of Aksum at the time. It is perhaps worth noting that these two names also appear in the 'official' Ethiopian kings list presented by Haile Selassie in 1922, published by REY (1935: 275). In this list 'Ezana is not mentioned, but it is now an accepted historical opinion that Abräha/Atsbäha are the same as 'Ezana. the 'House of Judah and of Solomon' (i.e., the Amhara-Tigray and their kings), an idea derived from the Kibrä Nägäst. Contrary to this, the Falasha always claimed that they themselves were the real representatives of the House of Judah (Bruce 1830-1832, IV: 217). Without being able to resolve the contradictions in Bruce's story, we may note that one can see here the expression of the ideological rivalry between the two groups. As a supplement to this version 1.a, one might consider the episode reported by Krempel (1972: 29). She heard this from several Beta Esra'el priests in the regions of Wägära and Simen:

$1 . b$

'Die Israeliten (gemeint sind die Falascha) sind die wahren Herren von Äthiopien. Die Amhara fielen vom wahren Glauben der Väter ab und nahmen das Christentum an. Unter den Priestern, die den Sohn Salomons nach Äthiopien begleiteten, befand sich auch Elieser. Er wurde zum Urvater eines Geschlechtes von Priestern, dem Pinchas entstammte. Als die Könige von Axum die Lehre von Maria und Christus annahmen und dem Glauben der Väter untreu wurden, rebellierte Pinchas. Er führte die Flüchtlinge an, die Axum aus Furcht vor der Rache der Könige verlassen mussten. Die wahren und treuen Israeliten ( = Falaschas) wollten keinen Verrat am Glauben Salomons üben.'

('The Israelites (i.e. the Falasha) are the real lords of Ethiopia. The Amhara abandoned the true faith of the fathers and accepted Christianity. Among the priests who accompanied the son of Solomon to Ethiopia was also Eliezer. He became the original ancestor of a family of priests from which also Pinchas descended. When the kings of Aksum adopted the teaching of Christ and Maria and became disloyal to the faith of the fathers, Pinchas rebelled. He led the refugees who had to leave Aksum for fear of the kings. The true and faithful Israelites (Falasha) did not want to betray the faith of Solomon.' [Translation is mine, JA]).

The name of 'Pinchas' seems to present an enigma; but the High Priest whom I interviewed about this point (the late Qes Birhan Biruch) told me that a Falasha chief with the name of Pinchas Zoanush had battled with the Abyssinian king Caleb. But from the fact that Caleb, as we saw, reigned in the 6th century and made war against the Himyarite king Yusuf Dhu Nawas, a convert to Judaism, it seems that we speak here not about an Ethiopian but a Yemenite king.

However, Qes Birhan's explanation is significant (see fn. 19). The choice of the Biblical name of Pinchas (a priest) in these stories is not without reason. It serves to project the origin and religious identity of the Judaic Beta Esra'el back into the history of Ethiopia, with reference to the politico-religious framework of the Kibrä Nägäst, of which the Beta Esra'el religious leaders were of course well aware.

Another interesting version is relevant at this point. It was also presented as response to the question of Beta Esra'el origins. The source is d'Abbadie (1851: 183).

1.c

'Nous sommes venus avec Salomon. Zogo, fils de la servante de la reine de Saba, est le père de Liqaunt. Nous sommes venus après Jérémie le prophète. Nous ne 
comptons pas depuis l'année de l'arrivée de Min Ylik ... . Nous vînmes sous Salomon; nous sommes venus par Sannar et, de là, à Aksum. Le monde resta sous une seule foi pendant 5500 ans, jusqu'à Jésus-Christ: nous sommes venus sous Salomon bien sûr.'

The informant giving this mysterious story was Abba Ishaq, an important spiritual chief of the Beta Esra'el (High priest and probably a monk (mänäkuse), residing at Hoharua, the location of an ancient Falasha monastery.

A last variant, also closely linked with the Ethiopian 'official' tradition of the Kibrä Nägäst, is the one given in Luzzato (1853: 489), quoting the book of the Anglican cleric S. Gobat (1834) who had heard this from an old Falasha woman:

1.d

$\because$. Salomon ayant eu un fils de la reine de Saba qui lui ressemblait si bien que les habitants de Jérusalem le prenaient pour lui, celui-ci, jaloux, le renvoya en lui disant d'aller prendre possession du royaume d'Abyssinie. Minylik, en sortant de Jérusalem, emporta avec lui l'Arche de l'Alliance et vint en Abyssinie avec un grand des juifs le jour du Sabbat, et depuis lors il fut chrétien avec tous ceux qui passèrent la rivière avec lui. Les Falachas sont les descendants de ceux qui restèrent attachés à la loi de Moïse et qui refusèrent de passer la rivière le jour du Sabbat. L'Arche est depuis lors restée à Axum [. . .], mais elle est inaccessible aux chrétiens, et ils n'y a que les Falachas qui puissent en approcher. Quand un Falacha savant et saint s'approche de l'endroit où est l'Arche, ses murailles se divisent en deux, jusqu'à ce qu'il en sorte après avoir fait ses adorations'.

All these mytho-legendary episodes so often told by the Beta Esra'el can be considered as elements of their self-definition as a non-Christian, non-Amhara Judaic group in Ethiopia, opposed to the mainstream. But it is obvious that in all these stories there is no evidence of an independent oral tradition, not tied to the Christian tradition: ${ }^{23}$ i.e. no strand of stories relating the period before ca. 1400 which relate to another mythical discourse. We might, for instance have expected a corpus of Agäw myths, or even relics of Yemenite (Himyarite) Jewish tradition-but no traces of this were found.

Perhaps it can be conjectured here that in the versions $1 . a$ and 1.d, in combination with the statements of Qes Birhan on Pinchas Zoanush and in the second part of 2.e, we see a projection, by way of analogy, the episode of the expedition of Caleb across the water (the Red Sea) against Yusuf Dhu Nawas (see also the interesting version 1.d), thus marking the start of the apostasy of the Abyssinian kings: abdicating the

23. Like AEŠCOLY (1962: 93) already said: ‘. . . cette tradition [that of the Falashas] n'a rien de Falasha en elle-même, à moins d'admettre que les chrétiens la doiven aux ancêtres des Falachas actuels ...'-which in itself is still a point of debate.

'real faith' by attacking the Himyarite Jewish king. Nevertheless, even in this case, the Beta Esra'el mytho-legend would have been derived from the Christian Solomonic discourse (cf. fn. 19).

To summarize the themes of the two strands of mytho-legend, we present the main outlines of the Amhara ideological model and oppose it to the Beta Esra'el model.

\section{Amhara-Tigray}

1. Because of the transfer of the Ark of the Covenant, the Ethiopians are, thanks people, according to God's decision. The ruse of Solomon (seducing Makeda) is revenged in the next generation by the ruse of Azariah and Menilek. The political-religious hegemony of the Ethiopians is established forever. Ethiopia, is the fulfilment and justification of the faith of the Ethiopians, as newly elected people, who became the new guardians of the Orthodox faith. 3. The Ark, symbol of divine election, is placed in Aksum in the church of Aksum-Siyon, and is inaccessible to nonAksurian (pagans, muslims, or Christians (pagans, muslims, or Falasha). 4. The Amhara, under their Solomonic kings, are the real masters of Ethiopia, designated as the undisputed political and religious sovereigns in all of Ethiopia.

5. The Amhara-Tigray and their kings descend from the important group of first-born Israelites, the Falasha who came as artisans and labourers are inferior to them (Krempel 1972: 24, 27) to Menilek-as mediator-the Elect

2. Christianity, which came later to

\section{Beta Esra'el}

1. The transfer of the Ark to Ethiopia is admitted. But the Ark has to be guarded/maintained by representatives of the first-born Israelites loyal to the Law of Solomon. The grace of God remains with the Ethiopians only as long as they remain true to the Israelite faith 24 of which they are the guardians.

2. The conversion to Christianity is an apostasy, already announced during the flight of Menilek and his party, when he traversed a river on the Sabbath (which was forbidden by religious law). 25

3. The Ark was indeed placed in Aksum but it is freely accessible only to the pious Beta Esra'el, who are its real guardians.

4. The Beta Esra'el, who kept the true Israelite faith, have a right, as legitimate as the Amhara, to govern Ethiopia, if not the whole country then certainly their own ancestral areas.

5. The Beta Esra'el descend from the first-born Israelites, who were the religious teachers and chiefs of Ethiopia, kept their faith, and thus are not inferior.

From this elementary comparison, one may conclude that the two groups, evincing a historic rivalry, had a kind of standing dispute about the interpretation of Ethiopian destiny and religious orthodoxy within

24. We should note that according to another story (see ABBADIE 1845b: 234) the Beta Esra'el called themselves 'Sons of Levi' - Levi being the tribe of the Israelite priests dispersed among the other tribes as the religious guardians and ritual mediators.

25. The Sabbath has become one of the crucial religious symbols of the Beta Esra'el. As d'ABBADIE's informant said (1845a: 56-57): 'Marie [. . .] est la médiatrice des Chrétiens: notre médiateur est samedi'. 
the same body of mytho-legends. (This makes their struggle fundamentally different from that between Ethiopian Christians and Muslims, which can be said to be the other great confrontation in medieval Ethiopian history.) However, one cannot draw any solid historical conclusions from this as far as ethnogenesis of groups like the Beta Esra'el is concerned.

We can also note the surprising difference between these Solomonic versions, current well into the 20th century, and the modern version of Beta Esra'el origins, as told by Qes Birhan. In the version 2.e, we saw a pseudohistorical account emphasizing the identity of the Beta Esra'el as an exiled Jewish community after the destruction of the Second Temple (586 B.C.E.). This fact of Jewish history (mentioned in the Bible) was considered as less doubtful than the 'Solomonic connection' explaining the existence of 'black Jews' in Ethiopia. The 2.e version is an effort to synchronize the history of the Beta Esra'el-Falasha with that of the other Jews in the world. We also note in it the claim that the Falasha would have arrived in Ethiopia before the Amhara, Tigray and 'Galla' (Oromo), and would have contributed to the civilization of the country also in a technological sense, thus proving them not to be intrinsically inferior.

\section{The Episode of 'Gudit' and the Zagwe: First Echos of History in the Oral Tradition of the Beta Esra'el}

The political events related to the decline of Aksum have also received mythical treatment, and now deserve closer attention. The historical element is much more evident here, but a mythical aspect still dominates the representation of events, also in Beta Esra'el tradition. When, in the 10th century, the Aksum kingdom was attacked by the Agäw, we see that the leader of the revolt was a certain unknown queen, who was later called 'Gudit' or Esatu. This second name, in Amharic 'the fire', is a mythical name, no doubt given because of the great devastation wrought by the revolt directed against many Christian buildings and treasures. From a historical point of view the revolt is indisputable, as is the role of a non-Christian, non-Aksumite queen. According to the Christian Ethiopian story, the Aksum cathedral was burned down by her. (The original Ark of the Covenant or Tabot had allegedly already been transported to the monastery of Däbrä Siyon, on an island in Lake Zeway, in the South). This queen was also said to have killed all members of the royal house of Aksum who were in Däbrä Damo at the time, except for one: Dil Nä'ad, son of the last king. He had fled to Shäwa region.

The Ethiopian sources on this episode are contradictory, ${ }^{26}$ and are not contemporary with the events. But the mytho-legendary interpretation

26. See also KREMPEL's remarks (1972: 15-16) on this point. is rather consistent: the queen was a violent 'Jewish' campaigner against Christian Abyssinian culture. She is thus represented as the complete antithesis of the rightful Abyssinian ruler as prescribed in the Kibrä Nägäst: a male descendant from the elect Solomonic line, 'Israelite', Christian, etc. She was modelled, in a mythical fashion, as the very negation of Makeda, the queen of Sheba: not only was she not a virgin (in some stories she is even presented as a former prostitute), but she wanted also to destroy the Ark of the Covenant, thus trying to destroy, not to conquer, the central symbol of Ethiopian divine electness; to replace the 'Israelite' dynasty (descendants of Menilek) with 'non-Israelites';27 to defy the prohibition of never crowning a female ruler over Ethiopia again after Makeda; and to give the power to 'the Jews'-which here might have meant: the opponents of the Christians, nothing more.

Thus, what Makeda, by her wisdom, had brought to Ethiopia, Gudit tried to invalidate and take away with her destructive campaign-this is the underlying idea of this mythical representation of Gudit/Esatu. This is the reason why she was represented as 'Jewish'.28 A rebellion was often considered as treason and 'apostasy'. As for the historical facts, it is certainly possible that 'Gudit' was a close ally or even (as the story says) the wife of a rebellious regional governor (in a region inhabited by Agäw people) who refused to pay the tribute he owed the Amhara king. She may have followed him in battle and taken over command after her husband had been subdued and killed.

It is significant that the Beta Esra'el also accepted this Gudit episode: this queen (also called Yodit or Yudit by them) came to be acknowledged as one of their own ancestors. ${ }^{29}$ She is said to have governed the country for forty years (this was also said by the Beta Esra'el). However, we do not possess any real information on this period.

Since 1137, the governing dynasty is that of the Zagwe, often said to be affiliated to Gudit's family, coming from the same area (Lasta). The Zagwe, however, were declared Christians, though not 'Solomonids'. I only mention them here again to point to the specific mytho-legendary interpretation they have undergone in the Beta Esra'el tradition. The latter, with an eye to the Solomonic ideas on the Zagwe, told stories of the following kind, summarizing some other written sources:

27. See the Kibrä Nägäst (in BudGe 1928: 213): ‘ . . thus the kingdom passed to another people, who were not of the tribe of Israel'

28. As noted above, we have reason to think that in the Ethiopian Middle Ages this word meant anyone opposed to organized Christianity, king or official Church See KAPLAN 1984: 19, KREMPEL 1972: 19.

29. It is more plausible to admit that she was a queen coming from the south (maybe Sidama plausible to admit that she was a queen coming from the south (maybe Sidama). Another source speaks of a pagan queen of the 'Bani al-Hamwiya' (TADDESSE 1972: 38-39). She dominated the Shäwa region during part of the 10th or 11th century (ibid.: 51). Compare also KREMPEL (1972: 14-15) and was 'Jewish' in the full sense. 

'Tradition has it that besides taking the Queen of Sheba into his bed King Solomon Tro worked his will on her servant who bore him a son called Zagwe. In due course Zagwe founded his own dynasty and his half-brother Menilek provided him with members of a bodyguard whom he had brought from Israel and they spread into the provinces of Wollo, Gojjam and Shoa, where they became the ancestors of the Falasha' (Kessler 1982: 81-82)

Kessler then adds: 'This is a variation on the Ethiopian tradition that the Agau tribe came into the country with the Army of Menilek I' (ibid.). However, it would seem highly unlikely that this story was of Beta Esra'el origin, because it would present them by definition as a kind of inferior group to the Solomonic Amhara: here they are descendants of slaves or servants, and this is what the Beta Esra'el always have tried to deny ideologically.

It is useful to recall the 1.c mytho-legend, in which there is an enigmatic phrase: 'Zogo, fils de la reine de Saba, est le père de Liqaunt' This seems to be a reference to the Zagwe ('Zogo'), and probably to the Qimant ethnic group ('Liqaunt', perhaps a corrupt transcription made by d'Abbadie). The Qimant are a small Agäw group living close to the Beta Esra'el, in the Gondär region. These Qimant had a kind of syncretic religion showing in common with the Beta Esra'el a remarkable number of Hebraic customs and beliefs (cf. Gamst 1969: $29 s q$.). It is possible that they were also influenced by the above-mentioned 'dissidents' from the Ethiopian Church (cf. Taddesse 1972: 109, Kaplan 1985a) at the same time as the Beta Esra'el (the groups shared Agäw origin). The Qimant, however, sought accomodation with the Amhara and did not systematically elaborate the Judaic elements in their culture. Notably, in the past century, the Beta Esra'el always tried to keep their distance from the supposed similarities between themselves and the Qimant (especially when facing Western Jewish visitors and researchers), saying that they had nothing to do with them

In the mytho-legend 1.c, which refers to the Zagwe, we see an inversion of the Amhara story concerning the Beta Esra'el, applying them in the negative to a group considered as 'non-Israelite' (despite the similarities, for which an explanation was not allowed in their mytho-legendary scheme). Such a projection would be irrational when applied to the Amhara, because the latter were, with their Kibrä Nägäst as charter and with their politico-military power position, the current masters of the Beta Esra'el.

Also in treating the Zagwe period and its echoes in the mytho-legendary tradition of the Beta Esra'el, we see that there is no autonomous, nonSolomonic oral tradition of the Beta Esra'el. Their stories relating to the pre-1400 period (roughly before the re-establishment of the Solomonic dynasty) form indeed part of one and the same mytho-discourse. We also know that this discourse was largely composed after the accession of Yikunno 'Amlak in 1270. Therefore, there is no solid point of reference for speculating about the ethnohistory of the Beta Esra'el-Falasha before this period, or about the existence of a specifically (presumably Mediterranean-derived) Jewish community in the Highlands of Ethiopia at that time: there is simply no solid evidence.

We reach this conclusion even apart from the purely historiographical arguments which could be adduced for it (Quirin 1977: 34, Abbink 1984b: 29-32). Nevertheless, it may be possible to push the time limit for the existence of the 'proto-Beta Esra'el' down to the 9th century at least (see also notes 18,19 and 30), on the condition that we accept the conclusions of Getatchew Haile (1982) on the date of the reign of the Aksumite king Gäbrä Mäsqäl: ca. 884 C.E. He concludes that this king, mentioned in the Kibrä Nägäst, was not (with Beta Esra'el) a son of Caleb, like Shahîd (1976) had suggested, except in a metaphorical sense. According to Getatchew, there are strong indications that the reign of Gäbrä Mäsqäl was a period of regeneration and reform of Christianity (in its ritual and liturgic aspects). The king's reforms led to a substantial departure of the old-style 'monotheists or Judaized Christians'. They left Aksum, seeking refuge in the Simen. ${ }^{30}$ This suggests a split of the JudaeoChristians away from the Ethiopian Church. (The Kibrä Nägäst would then be written to uphold the true orthodoxy of Gäbrä Mäsqäl against the deserters).

Be that as it may, this argument cannot refute the provisional conclusion that an old Judaic tradition originating from outside Ethiopia can hardly have been the formative influence on the ethnogenesis of groups like the Beta Esra'el-Falasha. ${ }^{31}$
30. GETATCHEW 1982: 319. In this connection, Getatchew is also inclined to adopt another date for the composition of the Kibrä Nägäst, because this work is for him the result of the conflicts evoked by the reforms of Gäbrä Mäsqäl: "The Kebrä Nägäst was composed most probably at the zenith of the reign of Gäbrä Mäsqäl in whom the Christians had hope to restore the glory of Kaleb's Axum by destroying their religious rivals' (ibid.: 320). His interpretation, based on the meticulous reading of sources, thus contradicts SHAHID (1976) who, however does not seem to be entirely refuted by it.

31. Gäbrä Mäsqäl's brother and political (and religious) contender was called Beta Esra'el (GETATCHEW 1982: 320). His followers may have taken his name. If this is the origin of the Falasha name 'Beta Esra'el', then again the roots of the eth nogenesis of the Ethiopian Jews would primarily lie in Ethiopia. 


\section{The Second Phase of the Mytho-Legendary Traditions: Religion, War and Resistance}

\section{Historical Recapitulation}

From the moment that the Beta Esra'el-Falasha appear on the historical scene of Solomonic Abyssinia (after 1400), their oral tradition takes on another shape. At this juncture, contemporary events and historical persons (and not the mythical ones like Makeda and Menilek) appear in their stories and legends. The themes of the stories are now not derived directly from a biblically oriented discourse shared with the Amhara Christians. No longer is the Kibrä Nägäst tradition the frame of reference of these mytho-legends. Instead, we see that primary allusions are made to Ethiopian religious-biographical texts or hagiographies (Gädlat), which relate the story and deeds of Ethiopian 'holy men', 'saints' or monks. As is well-known, this kind of religious men were important in the history of medieval Christian Ethiopia, especially after 1270 .

The background of this was the emergence of several new monastic movements which were not exclusively of an inward-religious nature. They often came from established and leading rural families and had explicit moral and political objectives, with normative standards also applied to secular rulers. As Kaplan (1984: 126) has noted, in a penetrating study of a number of edited and inedited hagiographic texts, these movements ... represented an attempt by regional groups to oppose the encroachment of the Solomonic kings on traditional rights and privileges. As the kings expanded their domain and reduced local rulers to vassal status, members of these local noble families abandoned the political arena and took up the monastic life'.

The study by J. Quirin (1977: 50 sq.) suggests that such a development also affected the Beta Esra'el, who, as a group of Agäw origin-in part linked to the Agäw of Lasta-had already undergone the influence of Christianity well before 1400 . As we will see, the fact that they had lost their political and economic autonomy, especially after the wars with king Yishaq, also explains their tenacious resistance in the sphere of religious life. The designation 'Beta Esra'el' may well have been adopted precisely in this period of wars, because they contested the waxing political authority of the Amhara and its ideological foundation-they did not accept the latters' pretention to be the only 'Israelites'.32 The Beta

32. Obviously, it would be completely wrong to consider the Beta Esra'el as linked in any way to the 'Israelites' of Amba Geshen, the famous rock-prison where all the lineal male descendants of Yikunno 'Amlak-potential rivals to the governing king-were confined in order to prevent them from usurping the throne, see TADDESSE 1972: 275, and also supra fn. 1 .
Esra'el thus claimed another right to the label 'Israelite', a word with such an ambiguous meaning in Abyssinian history.

It cannot be doubted that in this period the Beta Esra'el were significantly influenced by groups of so-called 'renegades', or political-religious protesters from the Christian ranks (Shelemay 1986). They thus penetrated the peripheral regions of the Christian empire, perhaps already as early as the period of the reforms of king Gäbrä Mäsqäl in the 9th century (see above). Around the end of the 13th and beginning of the 14th century, such 'holy men' suddenly appear as leaders of the Beta Esra'el.

The main events of this period of wars and resistance since the beginning of the 14th century have already been indicated above, but some more clarification can be given on this formative influence of Christian dissidents on a part of the Agäw populations which transformed themselves into Beta Esra'el. Later, we will describe another Agäw group (the Qimant) as a 'control group': they were submitted to a similar influence but showed, for various reasons, a very different reaction.

One more word on this perhaps unexpected fact of Christian influence on the Beta Esra'el. It can rightly be assumed the holy men or monks (in Amharic: mänañ, and later, mänäkuse) played a constitutive role for the Beta Esra'el community as such, together with traditional Beta Esra'el leaders influenced by them. But they did this in a special way. Were they received by an already formed Judaic community in the Highlands of Ethiopia? It does not seem likely-there is no real evidence. It is more probable that the Agäw who came to be called Beta Esra'el were familiar with Old Testament beliefs and customs, as a result of decades of missionizing influence (cf. Taddesse 1972: $196 \mathrm{sq}$.), which preceded the arrival of Christian dissident fugitives. But the decisive Judaic imprint seems to have been provided by those Christian 'renegades'. How can otherwise be explained the fact that the Beta Esra'el later proudly referred to these persons (Abba Sävra) as their leaders and the founders of their community? They were certainly not rabbinical leaders.

Let us now go back to the period of the wars in the early Solomonic dynasty. There were many revolts against royal authority, from the reign of king 'Amdä Siyon (1314-1344) up to that of Zär'a Ya'ekob (1434-1468). The ancestors of the Beta Esra'el as well as other non-Amhara groups inhabiting the regions of Ts'ällamt, Wägära, Simen et Ts'ägäde, close to Lasta, participated in those revolts. The chronicle of 'Amdä Siyon describes how the king waged battle against: '. . . the renegades similar to Jews (Ayhud, JA), the crucifiers'. These renegades would have been '. . . former Christians, but were now denying Christ . . . like the Jews' (Perruchon 1889: 339-340, my emphasis, JA). We cannot simply ignore these fairly specific expressions. The word 'Beta Esra'el' or 'Falasha' is never used in this chronicle. The last word only appears well after the promulgation of the so-called decree of king Yishaq (drawn up after his reign): in the chronicle of king Minas (1559-1563), who talks about 
'fälasyan', led by a chief called Rad'et. These 'Falasha' are certainly to be identified with the Judaic Beta Esra'el, no doubt about it. The word here no longer describes the general category of 'rebels' that we talked about earlier. But why and how did the proto-Beta Esra'el succeed in assimilating such Judaic ideas?

\section{The Role of Christian 'Dissidents': Mission and Interaction}

In many works on the Beta Esra'el we often find the statement that one cannot demonstrate the existence of a Jewish community in Ethiopia before the first decades of the 15th century, and that the terms 'Beta Esra'el', 'Falasha' or 'Ayhud' do not necessarily refer to one and the same people (Quirin 1977: 34, Kaplan 1984: 39-40, fn. 4). Obviously, one neither can give an outline of their society and their beliefs. But at the same time, it is asserted then that the Beta Esra'el suddenly are there, as a Jewish community. This argument is problematic: it is a projection back in time on the basis of modern points of view, and therefore unsatisfactory, because a real understanding can only be achieved on the basis of assessing the relevant historical conditions of the period. An example has been given by Shelemay $(1980,1986)$ who, on the basis of ethno-musicological data, analyzes in admirable detail the intensive mutual contacts of Christians and Agäw people. Liturgical music and texts (so often presented as the core of their identity) show a decisive influence of Christian liturgy (creatively modified by Beta Esra'el religious leaders) on Ethiopian Jewish tradition (Shelemay 1980: 242). It came to them by fugitive Christian dissidents who settled among them. Why had these clerics been fleeing from the royal sphere of influence? It has to be recognized that the general relation between the kings and the Christian clerics was never smooth. In the years following the institution of the monarchy in 1270, the Christian clerics represented an independent spiritual force, wielding a kind of normative authority. They did not hesitate to seriously criticize the politics and the personal behaviour of a king, if they saw fit. As a result, serious conflicts could arise between king and clerics (see Kaplan 1984: 126). If we add to this the fact that these clerics were often scions of regionally powerful old families, it seems evident that political next to religious tensions were at stake, which could sometimes lead to repression or persecution.

In the 14th and 15th century, the three main oppositional movements were the Ewostatians (named after Abba Ewost'at'ewos, living at the end of the 13th and beginning of the 14th century), the movement of the Shäwans (coming from the region of Shäwa), and that of the Stephanites (who followed the doctrine of Abba Est'ifanos, 14th and 15th century). Representatives of all three groups were probably active among the Agäw (although the case of the Shäwans is hardly documented yet).
All three emphasized beliefs and customs of the Old Testament much more than the old Church was doing. For example, the Ewostatians revered the Sabbath day and had a different view on the cult of Mary. According to Kaplan (1984: 10), citing hagiographies of several saints, the Ewostatian leader Gäbrä Iäysus was active among the 'Sons of the Jews' during the second half of the 14th century. Later, during the reign of king Dawit (1383-1412), the monk Qozemos 'lived among the Jews' and led them into a violent campaign against the Solomonic authorities.

With regard to the Stephanites, Kaplan (1984: 42) remarks that they were very critical of certain kings of that period. Like the Ewostatians, they were also severely persecuted, but more for their refusal to submit to the royal power than for their 'heretical' religious practices (ibid.: 43). It seems that the proto-Beta Esra'el did not 'convert' to the Christianity of these sects, but borrowed key ideas from them and religious symbols (the symbols of the day) with which they could express their fundamental opposition to the central royal authority and to its religious exclusivism: veneration of the Sabbath, the idea of their 'real Israelite' descent, different views or even rejection of the cult of Mary, refusal to prostate before the kings as a divine person, and last but not least, the adoption of the 'monastic model' of leadership, on the basis of which rebellion and judgement of the established Solomonic Christians could be justified. It is well to remember the general character of the rebellion of groups led by 'holy men':

'The rebel clerics sought to fill the prophetic role assigned to them in the Kebrä Nägäst. The king, they argued, was first and foremost a Christian and hence subject to the same laws as any believer ... . His claim to own all land in the kingdom could not be accepted since the land belonged to God (ibid.: 36-37).

Such ideas were transmitted to the proto-Beta Esra'el and elaborated in a politico-religious form. Thus, a 'counter-ideology', emerged, which soon rooted itself in the domain of religious life and ritual (liturgy, prayers, music). ${ }^{33}$ The saints or holy men (or in the Beta Esra'el case 'monks') could take this role of political and cultural counter-ideologues only after the Beta Esra'el had lost their traditional territorial chiefs and their autonomy. In their oral tradition these former political chiefs were referred to as gedewon $^{34}$ (no one knows since when, but perhaps retrospectively, after the 15th century), a title taken from the Old Testament (Judges 6-8).

33. SHELEMAY (1980: 242) has suggested that the 'Falasha' liturgy, as it existed in the Beta Esra'el villages until recent years ‘. . . is primarily the product of the fourteenth intense contact with Ethiopian Christian monks and adopted a monastic institution'. See also SHELEMAY 1986.

34. The number of gedewons is unknown. It seems to have been a title indeed; perhaps only the first chief was called Gedewon. We only have some of the proper names: Rad'et, Rädai. Some of my informants (such as Qes Birhan, cited above) 


\section{The Fall of the Political Chiefs}

This change in the structure of traditional authority among the Beta Esra'el is an intriguing but yet ill-understood issue because of the lack of historical data. An informant of d'Abbadie (1851: 267) was the first to mention an interesting oral tradition referring to the time of the wars against king Yishaq. It has been elaborated by Taddesse Tamrat (1972: 200) and by Quirin (1977: 57-58), who found a similar tradition among his own informants of the 1970's. It states that there was an internal conflict within Beta Esra'el society, dividing them into two camps: one around a person called Bägädosh, a representative of a younger generation; the other around a governor called Bet-Ajir, ${ }^{35}$ who was installed by king Yishaq (!) and was a member of the established 'ruling family'. However, the members of the reigning family were not inclined to submit themselves completely to Yishaq, as he demanded, or refused to hand over the feudal tributes due to him. However, the young ones favoured an accomodation with the king in order to maintain the peace. But they were not listened to. Thereupon the young party went to Yishaq's court to put themselves under his protection (probably hoping to reap the personal benefits of this in terms of new positions and resources). The king invaded the Wägära region, domain of the Beta Esra'el, subdued them by force and killed their political chief, Gedewon.

We have here a very fascinating episode, which indicates a strange but telling liaison between the Beta Esra'el and the Amhara rulers, who came in to conquer the territory of the former on the invitation of a part of the Beta Esra'el. This does not present us with a picture of a vehement religious conflict of the Amhara with an autonomous Jewish community (neither with a 'Falasha kingdom') but rather shows a kind of partial political integration of people called Beta Esra'el in the established Amharadominated structure. The proof of this is that Yishaq could have installed an important chief (Bet-Ajir) as governor of one of their 'own' regions and at the same time maintain a liaison chief (Bägädosh) with the royal court (according to the Tarikä Nägäst, a document cited by Taddesse Tamrat 1972: 200). mentioned seven gedewons; others said there were eleven, or even forty. Let us recal the words of Abba Ishaq, d'ABBADIE's informant (1851: 184): 'Notre Gédéon était seulement un petit chef: les Falasha n'ont jamais ete rois en Abyssinie'. Compare 'GETATCHEW HAILE (1982: 319) who offers the hypothesis that the chief of the 'monotheist' rebels in the reign of king

35. D'ABBADIE's informant (1851: 267-268) described Bëtajir (sic) as the daughter of Gedeon: 'Gédéon régnait en Simen et a fille Bëtajir lui prédit qu'il serait battu par un homme du sud. En effet, son fils Zanacina alla en Shäwa montrer battu par un hommé du sud. En effet, son fils Zanacina alla en Shäwa montrer au roi de la rivière Bashilo: Yshaq marcha ensuite vers le Wagara et battit les Falasha dans la plaine d'Anjiba'.
After this bloody conquest, the political autonomy of the regions inhabited by (what strictly speaking still were) proto-Beta Esra'el-Agäw disappears. The political chiefs effectively lost their power and may have been eradicated as a group itself. Like it was said by the widow of the last gedewon (according to an oral tradition told to me by a Beta Esra'el now living in Israel): 'From now on, there is no longer a king among the Beta Esra'el, the head of our people has been cut off!'

The only political chiefs that the Beta Esra'el were to know in subsequent ages (especially after the 17th century), were the village chiefs (chiqa shum). They had very limited authority and served only as village representatives in contacts with outsiders.

The 'Monks', New Chiefs of the Beta Esra'el:

The Legend of Abba Sävra

Why is it important to stress the afore-mentioned distinction between the contents of the oral traditions of the Beta Esra'el of the pre-14th century period and the period after it? Because of the following reasons: 1) the differences of style, content and message are markedly notable for every reader; 2 ) the role of a certain type of politico-religious chiefs suddenly appears crucial; some of them are ascribed a formative influence for the Beta Esra'el religion and identity as a whole; 3) there are also remarkable parallels in the culture, literature, liturgy and religious music, parallels which draw from common sources, or are transformations of each other; 4) the legends about certain 'monks' or 'holy men' have, until this day, been a normative tradition for the Beta Esra'el religious leaders (including the priests who have recently immigrated to Israel). ${ }^{36}$

The Beta Esra'el stories referring to the second period-i.e., the period after the 14th century-resemble legends or stories in the proper sense of the word, although they retain a mytho-legendary element. They are probably based on historical persons, to which miraculous deeds are ascribed. They cannot be considered on a par with the Solomonic stories of the first period. It seems that the 'historical memory' of the Beta Esra'el

36. For instance, one of these priests, interviewed several months after his immigration to the country, told me (Nov. 1982): 'Abba Sävra, he is the greatest. He gave us the rules with which we, the Beta Esra'el, have lived up to this day. Was the most important 'holy man' or 'monk' in Beta Esra'el history. It can was the most important 'holy man' or 'monk' in Beta Esra'el history. It can
be predicted that in the very near future, the priests will no longer be willing be predicted that in the very near future, the priests will no longer be willing king, they feel that stories about 'holy men' are anomalous, deviant, and place them outside the mainstream of Jewish history. They also partly adapt to rabbinic Judaism and unlearn the Beta Esra'el ways. 
itself is modified: they do no longer borrow in a direct manner from the Christian stories, inverting key episodes or religious themes; on the contrary, they talk of their own saints, especially of Abba Sävra (who is not known in a Christian version). But parallels remain. It can be seen that in the same way that the Solomonic mytho-legends (set in the pre-1270 period) show recourse to an already formed (Christian) tradition, the postSolomonic Beta Esra'el legends of saints (set after 1270) come from a common genre of Gädlat, saints' stories, although in an unwritten form.

For instance, the role which Abba Sävra plays in the Beta Esra'el stories is fairly similar to the role played by saints as the Christian Ethiopians know them. ${ }^{37}$ The saints or monks venerated by the Beta Esra'el were not numerous. Most of the names can be found in the studies by Leslau (1975) and Ben Dor (1985), although the Beta Esra'el-Falasha identity of all of the persons mentioned is not always clear. It is equally difficult to put the names in a chronological order, or to determine under which kings they lived. It seems that the various informants do not attach great importance to this. They always refer to the same kind of situation: a state of politico-religious rebellion against a Christian Abyssinian king trying to subdue them or even to eliminate them and to root out their belief. This is the recurring great historical theme in all these legends, and it dates from the reign of king Yishaq. As our interest here chiefly regards the question of ethnogenesis, we will limit ourselves to discuss only the earliest bunch of saints appearing in those traditions of this crucial period. We then arrive at four key names: Abba Halen, Abba Ybarakanna, Abba Sävra, Abba Ts'ägamlak.

It has to be noted that we ignore the Christian saints who may have had a direct influence on the proto-Beta Esra'el, but who are not found in their own oral tradition: Gäbrä Iäysus and Qozemas (14th century); Täklä Hawaryat (15th century); and Gäbrä Mäsih (16th century) (Kaplan 1984: 40-42, 1985b: 12-14); nor do we know the saints who lived after Abba Sävra and Abba Ts'ägamlak (Leslau 1975, Ben Dor 1985).

On Abba Halen, there is very little information left. He was probably a Christian saint from the 14th century. He has to be mentioned because of the response given by d'Abbadie's informant (1851: 184) on a question of Beta Esra'el history. He said: 'Nous n'avons d'autres histoires que celles d'Abba Sabra, Zaga Amlak . . . . Abba Batui, et Abba Halën. Ces quatres saints étaient des contemporains .... Le passage de Saint Paul est d'Abba Halën'.

37. I heard Beta Esra'el elders in Israel admit that Abba Sävra might have originally been a Christian. As a matter of fact, one of Shoshannah BEN DOR's informants (1985: 42) also stated that Abba Sävra and another saint of that period
(Abba Ts'ägamlak) were Christians who converted to the faith of the Beta Esra'el.
One can, unfortunately, hardly draw any conclusions from these enigmatic and very succinct remarks. Abba Batui is unknown. The 'passage de Saint Paul', however, seems to refer to a (Christian) text written or adapted by Halen. He is also mentioned (as 'Halien') by J. Halévy (1877a: 230, who also cites his other name: 'Abba Sakhooyan'), and is said to be the author of a collection of prayers entitled Sa'atat (Halévy 1877b). Taamrat Emanuel has also gathered a tradition on Abba Halen, but it describes only his custom of offering sacrifices on a stone altar (Leslau 1975: 627). Abba Halen was often confused with a saint called Abba Däbätära, who lived later (ibid.).

There is a possibility that $A b b a$ Ybarakanna is the same person as $A b b a$ Yafqirännä-Egzi' whom we know was a Christian (Conti Rossini 1919-1920, Wajnberg 1936). He lived in the reign of king Dawit (1382-1412). In the response of d'Abbadie's informant (1851: 184), we read also: 'Nous avons encore la vie (the Gädl, JA) d'Abba Ybarakanna, fils d'Abba Halën'. Now if Abba Halen was the son ('le fils') of Abba Ybarakanna, and if the latter is to be identified with Yafqirännä, it follows that they were never contemporaries of Abba Sävra and Abba Ts'ägamlak, who, according to the dominant oral traditions, no doubt lived in the reigns of kings Yishaq et Zär'a Ya'ekob.

It will not be necessary to pursue the biography of Abba YbarakannaYafqirännä, 38 because no other informant of the Beta Esra'el has accorded him any notable role. Before treating the next saint we have to mark one other episode, in the Gädlä Yafqirännä-Egzi' (Wajnberg 1936: 53-59), concerning the afore-mentioned renegade monk, Qozemas (end of the 14th century). After his flight from a Christian monastery he was cared for by people living 'in the Jewish faith' (in Ge'ez: bähaymanotä ayhudi) and was said to have copied the Bible (Ge'ez: 'Orit) for them. Later he took command of an army formed from the people amongst whom he had found refuge and by whom he was considered as 'the son of God' (Messiah). He attacked the churches of the region and killed 'many governors and princes' (ibid.: 59), before being killed himself by 'Akhadom, the governor of Tigray. His personal example in leading battle is possibly the reason why the text designates him as a 'second Pinchas' (ibid.): a reference drawn from the Kibrä Nägäst. This again underlines the political identification of the proto-Beta Esra'el with the vanquished Judaic king of Himyar (Pinchas Zoanush) as noted by the Christian author of the Gädl text. Despite this story, Qozemas is never mentioned in any oral tradition of the Beta Esra'el. My informants did not know this name.

38. Another possibility would be that Abba Ybarakanna is to be identified with Abba Abäkäräzun, a Stephanite of the 15th century. On this saint, see KAPLAN 1984: $48,52-53$ 
Thus we arrive at the key personage of the oral history of the Beta Esra'el: Abba Sävra (also written as Säbra, Sabra, Sivra). He is, without any doubt, the first monk or saint in their old tradition, even until recently venerated by their elders and priests as the source and the guardian of the faith and the ways of the Beta Esra'el. Abba Sävra only figures in the oral tradition of the Beta Esra'el, not in that of the Ethiopian Christians. There are no written sources on this person. A Gädlä Abba Sävra about whom one hears rumours now and then, does not exist. As we have suggested earlier, the role of Abba Sävra as a saint should be interpreted within the context of the movement of Christian dissidents allying themselves with non-Amharized peoples outside or in the margins of the Solomonic empire.

The Beta Esra'el have always ascribed the qualities of a prophet to Abba Sävra. The first testimonies about him (Abbadie 1851: 184, 263; Halévy 1877a: 227, 230), as well as the more recent ones (Quirin 1977: 62-63; Abbink 1984b: 31-32; Ben Dor 1985: 42-43), show that Abba Sävra, as a 'monk' (he was described as a mänañ), was declared to be the 'source' of the constitutive ideas and normative rituals which contributed to the ethno-religious identity of the Beta Esra'el.

From the responses of some Beta Esra'el elders, Quirin's remarks (1977: 85 ) that the period in which Abba Sävra lived is pushed back to the alleged origins of the Betä Israel in Ethiopia, and thus gives his memory the increased veneration of antiquity; and Quirin pursues in a note:

'These origins are sometimes reputed to have been at the time of the legendary Menelik I in the first millennium B.C. or after the prophet Jeremiah in the fifth century A.D. [sic, we should read here: B.C., JA], or at the time of the Axumite expeditions to South Arabia between the third and the sixth centuries A.D. ...

What is important here is not the actual content of this tradition, but the fact that the whole pre-Solomonic period is, so to speak, subsumed under the period actually considered to be the crucial one for the formation of their faith and their identity as transmitted up to the 19th and 20th century: the episode of the 'monastic reform'. As stated by his informants, continues Quirin, '[Abba Sävra] is said to have established the laws for the Beta Esra'el, that is, the religious codes through which their monks and priests henceforth taught the people the correct way to live' (ibid.).

According to a widespread tradition, but one about which the Beta Esra'el only speak with reserve, Abba Sävra was indeed a Christian. After having committed a murder, he sought refuge among the proto-Beta Esra'el and 'converted to the Israelite faith' (Ben Dor 1985: 42, and Taamrat in Leslau 1975: 624). But, Taamrat continues: 'He taught the Orit in all the regions where he thought that the Falashas applied it incorrectly'. This would appear rather strange for a neophyte. It is perhaps better to suppose that Abba Sävra did not convert to a Jewish-Israelite faith already well-established among the Beta Esra'el-Falasha, but that he continued to forge a corpus of heterodox ideas (accepted by them during-at least-several decades before he arrived among them) into a new synthesis, thus giving them a definitive and more militant form. As a result, the disoriented and leaderless Beta Esra'el of that time were able to form a new model of internal authority and a charter for resistance (Shelemay 1980: 244, Abbink 1984b: 31-32). Notable is that Abba Sävra was always credited with having introduced the rules of purification (in Amharic: attänkunye, 'don't touch me'): all physical contact with non-Israelite persons should be avoided, and if it occurred, a Beta Esra'el had to ritually cleanse him- or herself. These rules evidently instituted a fairly strong social boundary, and they were in vigour until the 20th century, especially for monks and priests. As an intinerant preacher and reformer, Abba Sävra also instituted new prayers, codified religious literature (on the basis of Christian texts), drew up liturgical rules for the Beta Esra'el monks, and founded the 'monasteries', places of repose for religious life and meditation, at Hoharua and Mudraro that also functioned as schools for the new leadership. He continued to evade Abyssinian soldiers after he had (according to the legend) succeeded in converting a son of the king to his faith. His death was shrouded in mystery. One informant, an old priest of the Beta Esra'el now in Israel said to me that: '. . . Abba Sävra never died; I mean, no one knows what his end was. They say that he did not die, he has just disappeared. God may have taken him suddenly, from an unknown place, perhaps Hoharua' (a holy place for the Beta Esra'el). 'There is no grave of Abba Sävra, no one knows the place', he concluded. ${ }^{39}$

We can therefore certainly infer that in forging the outlines of the ethno-religious identity of the Beta Esra'el, Abba Sävra was indeed 'the greatest', and judging from form, not content, was a holy man, quite in line with those of the Ethiopian Christians. It is not without reason that the Beta Esra'el elders have given him pride of place in their oral traditions. There is no doubt that other saints have been active after him (Leslau 1975, Ben Dor 1985), but all stand in his shadow. The historical reconstruction which Quirin has given us (1977: 58 sq.) - seen together with the internal logic of the oral tradition just sketched-permits us to say that Abba Sävra indeed was an historical person living at the time of kings Yishaq and perhaps Zär'a Ya'ekob. Possibly, the well-known effect of 'telescoping' has also been at work in this Abba Sävra traditionthe Beta Esra'el declaring him to be the only instigator or creator of their beliefs and their way of life-'Everything started with Abba Sävra'-,

39. Qes Yishaq Iyasu, former High Priest of the Beta Esra'el in the Tigray region, 
and thus simplifying what may have been a more extended and complex historical process, involving many more persons. But this does not invalidate the argument made here that a basic gap exists in the oral traditions, severing the periods before and after king Yishaq's reign. We see two referential discourses, which do not show any continuity. They make incompatible claims as to the origins of the Beta Esra'el Judaic faith. The Solomonic stories of the Beta Esra'el derive from the established Christian versions; the post-1400 saints' stories stand on their own. Abba Sävra is not connected to the Menilek myth or to the Pinchas Zoanush story.

On $A b b a$ Ts'ägamlak (also written Tagamlak, Saga Amlak) one can be brief. He is always presented as a follower or companion of Abba Sävra, and is sometimes identified as his son by d'Abbadie's informants (1851: 184) and Halévy (1877a: 230). But more often he appears as the firstborn son of king Zär'a Ya'ekob, who was an ardent Christian and strongly anti-pagan and opposed to the Jewish faith. According to the legend, Ts'ägamlak was the first person who converted to the Beta Esra'el faith as defined by Abba Sävra, following the conversion rite outlined in Leslau (1957: 73).

Two of my informants in Israel, Qes Birhan of the region of Gondär and Qes Yishaq of the region of Tigray (who were interviewed independently and were always in agreement on the main points of oral tradition), also emphasized that Abba Ts'ägamlak was certainly not Abba Sävra's but Zär'a Ya'ekob's son. Why has this to be emphasized? First of all, because we see here a nice inversion: the Beta Esra'el label the preferred pupil of their 'prophet' Abba Sävra as the son of the fanatical and Orthodox Christian king. Thus they were expressing the spiritual superiority of their own tradition, which could even attract such a close kinsman of the enemy king, while his own predecessor, king Yishaq, was thought to have vanquished the Beta Esra'el and to have rooted out their so-called 'renegade' belief and had denied them all political rights and power. The story of the conversion of the son of the new king would serve to show the tenacity and vigour of the Beta Esra'el religion and the force of their continued political claims. Secondly, it cannot be excluded that Abba Ts'ägamlak really was Zär'a Ya'ekob's son. This is in accordance with the general character of this mytho-legendary tradition, where historical elements had a much greater role to play.

The Emerging Social Frontier between Amhara Christians and Judaic Beta Esra'el

The above thesis of a significant breach in mytho-legendary traditions is corroborated by the importance which all informants have always given to the 'Jewish-Israelite' customs which were allegedly prescribed by Abba Sävra. It is necessary to enumerate the vital points of these customs, which had their effect on the interrelations between Beta Esra'el, Amhara and other ethno-religious groups within the Abyssinian feudalist social formation. They established a kind of social boundary, which was perhaps not stricly observed in all contexts, but served as an ideologically normative, cultural boundary. Among such 'boundary customs' emphasized by the Beta Esra'el one can note:

- the veneration of the sabbath (Sänbät) as a central religious symbol; - the purification rules (attänkunye);

- the predominant veneration of the Pentateuch ('Orit) and the total rejection of the 'New Testament' of the Christians;40

- maintenance of sacrificial rites (Biblical, for instance the one on the day of Easter [Fäsika], but also those which had an Agäw basis);

- the ritual isolation of women during their period of menstruation, or after their having given birth (perhaps also an element of the Agäw culture); - the use of religious texts similar to (usually on the basis of) Christian texts, ${ }^{41}$ although they were thoroughly re-edited (all references to Christ, Mary, or the Holy Ghost being eliminated); and the creation of new prayers-the religious creativity and originality of the Beta Esra'el most clearly appears in these prayers, which are often of a moving beauty and don't have a Christian ring to them;

- the institution of a Toranic kashrut (i.e., rules for the ritual preparation of food and for slaughtering animals, derived from the Pentateuch); they were different and more severe compared to those of the Christians, who were also inspired by the biblical alimentary rules. In addition, the Beta Esra'el refused to consume any nourishment or drink touched or prepared by an Amhara or other outsider;

- the introduction of a hierarchy of religious functionaries: monks (mänañ,

40. It has to be noted that Abba Ishaq, d'ABBADIE's priestly Beta Esra'el informant, was also consulted by Christians on his region. In his Journal de voyage qu'on a sérieusement propose qu'on a sérieusement propose de s'adresser à lui pour enseigner aux professeurs écoles non Falacha'. It is therefore possible that the Beta Erd'hui perdues dans les ecoles non Falacha'. It is therefore possible that the Beta Esra'el clergy had retained (although a consultation on the subject that the Christians no longer possessed (although a consultation on the subject of the New Testament would probably Judaic Beta Esra'el and the Orthodox Christians, who shared link between the discourse, and it does not allow us to conclude that the Beta Esra'el in general were a primary source for the formation of the Christians doctrines.

41. This even seems to hold for the Te'ezazä Sänbät, or 'Commandments of the Sabbath', often considered to be an original Beta Esra'el work. See KAPLAN's study (1987) who concludes that the author of the Te'ezazä Sänbät was a Beta Esra'el, but wrote his text on the basis of several Christian tracts. 
or mänäkuse), priests (qes), non-ordained clerics (däbtiras) and deacons (diyaqon), 42 installed according to their own proper rituals.

In this manner, the new ideological and cultural basis of the Beta Esra'el community was established. The Beta Esra'el could define themselves, despite their political and economic marginalization, as the true Israelites, as inheritors of ancient traditions. They defended their newlywon identity and way of life in a prolonged series of wars, aimed at maintaining or recovering their politico-economic autonomy and land rights. They were, as we saw above, decisively defeated in the period 1616-1624, by king Susneyos' troops. At that time, they lost any semblance of autonomy, and were forced to live by their craftsmanship. They were dispersed, declined in numbers but did not disappear. The politicomilitary, and later also cultural, dominance of the Amhara did not completely extinguish their ethno-religious heritage and identity: the Ethiopian Christians for them remained the 'apostates'. As Abba Ishaq, d'Abbadie's informant $(1851: 266)$ had said: 'Notre foi est la vraie foi'. This belief was the basis of their whole reinterpretation of the historicist, mytholegendary tradition of the Kibrä Nägäst, as analysed in the first part of this article.

\section{The Curious Case of the Qimant}

We have seen that the Beta Esra'el, as a population finding its origins mostly in the Agäw peoples, developed a form of indigenous Toranic Judaism, in Ethiopia itself. This occurred within the specific conditions of the Ethiopian socio-political formation. Their beliefs and group identity later (in the 20th century) evolved toward modern, contemporary Judaism, but not before the intensification of contacts with visiting groups of western Jews and travellers. During the long period of evolution of their religious culture, they neither had direct Jewish sources (Yemen or Egypt or the Holy Land) which could have inspired them, nor is there any documented immigration of Jewish groups to Northern Ethiopia. Certainly, the attitude of the Amhara-Tigray-interpreting their conflict with those Agäw rebels within the broad context of the Kibrä Nägäst and thus designating their opponents as $A y h u d^{43}$ - has stimulated such a development toward Judaism. It is also in this era, in the second half

42. It seems unlikely that the religious leaders of the proto-Beta Esra'el were already 'priests' or 'deacons', etc. They were probably traditional chiefs like those found among the Agäw people.

43. It is significant that neither the term Agäw nor the other ethnonyms of the Agäw populations (like Hawiya, Kunfal, Bilen, etc.) are found in the Ethiopian royal chronicles of this period, and very rarely in other religious or historical documents. For an example from the 16th century, however, see TADDESSE 1972: 29, fn. 1 . of the 15th century approximately, that the first ('eye witness') reports of the existence of 'Ethiopian Jews' start to be written and to penetrate in Europe and the Jewish world. Nevertheless, the unique character of the Beta Esra'el emerges very clearly when we compare them with another Agäw group of Ethiopia, which showed a quite different reaction to the Amhara expansion of that time: the Qimant.

Several authors writing about the Beta Esra'el-Falasha have also often drawn attention to this ethnic group, living in their vicinity. From James Bruce (1830-32, V: 39-40) up to James Quirin (1977: 255 sq.), scholars have emphasized the curious similarity between the two groups. Our knowledge of the Qimant (or as some sources write, Camaountes, Kemmont, Kemant) has been considerably advanced by Fred Gamst's study of 1969 . But even after the publication of this monograph, few scholars have focused their attention to comparing the culture and religion of both groups. Making such a comparison is, however, relevant to our subject, the ethnogenesis and historical development of the Beta Esra'el.

According to Gamst (1969:1), in the 1960's the Qimant were a group of ca. 20,000 people, inhabiting the region of Ch'ilga, south-west of the Beta Esra'el area, near the city of Gondär and Lake T'ana. Until the reign of Emperor Yohannis IV, who, in the 1880's, started a big campaign to convert the non-Christian Ethiopians, the Qimant had been able to maintain their religion and way of life relatively intact and to keep a measure of economic autonomy in their native region.

It is difficult to deny that the Qimant and the Beta Esra'el both have a common origin in the Agäw population of the Ethiopian Highlands. This may explain the extent of their historical and cultural similarities (apart from their similar physical type), among which we note that:

- both groups formerly (up to the late 19th century) spoke Agäw languages (which were mutually intelligible);

- they had religious concepts similar in origin (the two names for the SkyGod, Adära and Herzigane or Herzigaye; also several names of local spirits); - they produced a similar habitat and material culture (technology, clothing, tools, etc.);

- they had common elements of social organisation (like the descriptive kinship terminology, the community authority structure of priests and elders, ideas about relations between the sexes and their division of labour); - various customs and rituals were the same, e.g., offerings and sacrifices, ritual isolation of women in their menstrual period or after childbirth, the norm of monogamy, zar spirit possession, religious services in prayer houses and on sacred hills.

No doubt, there were as well significant dissimilarities (mainly in core religious ideas), which emerged as a result of firstly, the transformation of Agäw cultural elements in Beta Esra'el group culture, especially after 
the 15th century, and, secondly, as a result of the process of interaction with the Amhara. The Qimant also had a different economic base. The main thing is that they did not develop craft specializations, but remained peasant-cultivators in their ancestral area. As we have seen, the Beta Esra'el lost their traditional rights of possesion and free cultivation of the land in the wake of the conflicts with the Amhara-Tigray and were forcefully dispersed as artisans, masons, etc.

In the 20th century, the religious identification of the Beta Esra'el with modern Judaism became very important, and their religious culture began to deviate more and more from that of the Qimant. Despite this (recent) development, it is impossible to deny the close historical and cultural link which once existed between the two peoples. A telling episode in the oral tradition of the Qimant is one origin story which says that the main ancestor of the Qimant, called Aydarki, had three wives, the first one of which (Anzakona) was the mother-ancestor of the Qimant while the third one, Feinabahura, was the ancestress of the 'Falasha'. Gamst also notes (1969: 36-37) that the Qimant said they received their land from a 'king of the Falasha Agaw who gave them as much land as they could ride across on horseback before sunset. Gadhu stopped the sun for three days to increase the amount of land that could be acquired in this way'.

The author adds: 'This tale helps to validate Qemant claims to land and reflects animosity between the Qemant and the once formidable Falasha' (ibid.: 37). But the oral tradition of the Beta Esra'el does not recognize any liaison with the Qimant, or has supressed it. We have already noted that the attitude of the Beta Esra'el towards the Qimant was marked by profound ambiguity: in public, they denied every affinity or contacts with the latter, 44 and considered themselves superior to them. When he was asked about this, d'Abbadie's informant said: 'Les Qimant n'ont rien à faire avec nous et n'ont pas de livres. Leur langue est un dialecte de la nôtre' (Abbadie 1851: 263). Flad, the 19th century missionary among the Beta Esra'el, notes (1869: 75) that the 'Falasha' (as well as the Christian Amhara) accused the Qimant of having 'barbaric customs'. But this is a typical example of out-group stereotyping which has little to do with the facts.

However, similarities between the two groups are evident and significant, and some Beta Esra'el informants have assured me that, basically, relations between them were not so bad either. Contacts between their leaders were even often of a confidential nature; for example, when they were faced with the need to defend common interests vis-àvis the Amhara. One is inclined to believe that it was only in order to hide their similarities with the Qimant that the Beta Esra'el have always tried to distance themselves from the this group. 45

While the cultural and historical affinity between the two peoples no longer presents a puzzle, the evolution of Beta Esra'el identity points to the fact that they have, as a group of Agäw origin, presented a different reaction to the 'Amhara challenge' which manifested itself in their region. It is here, as Quirin (1977: $263 s q$.) has rightly emphasized, that one encounters the crucial element: while the Beta Esra'el came to oppose the encroaching Amhara and always contested their pretentions of sovereignty and religious superiority, the Qimant have, in an early stage of their encounter with the Amhara, accepted the new power (after perhaps a battle or two), (ibid.: 306, fn. 29). In return for the payment of tributes and political submission, they were spared violent conquest by the royal armies and could maintain their internal autonomy in matters of religion and way of life (Gamst 1969: 117-118, Quirin 1977: 274). In addition, when the Amhara armies started to penetrate their region (in the 15th century), the Qimant also nominally adopted the Christian faith. It seems probable that the Qimant were also missionized by members of the Orthodox Ethiopian clergy. But, having accepted the political regime of the Solomonic Amhara kings, they refused to assist or shelter Christian dissident groups, like the Beta Esra'el had done, and dissociated themselves from such groups when these continued to oppose the Amhara. Because of this 'strategy of submission', the Qimant never lost their land-rights, and remained more or less independent cultivators. While they had presented themselves as being Christians, they continued to practise their tribal rituals, maintained their traditional community chiefs, and succeeded in more or less concealing their specific religious ways until well into the 20th century. The Amhara did not take offence to this because the Qimant did not present an ideological challenge to them in any way. And thus, the Qimant were able to 'retreat' into their own way of life, but did not-in contrast with the Beta Esra'el-feel the need to institute a fundamental 'social boundary' between themselves and the wider society. They did not institute the rules of personal ritual purification (the attänkunye of the Beta Esra'el); they did not have rules or rituals which were ideologicaly opposed to the Christian Amhara (e.g., ideas concerning the royalty, the 'Israelite' faith, the sabbath as a symbol of opposition); they did not have strict biblical taboos on the partaking of food, or of meat from animals slaughtered by non-Qimant; they did not follow a strict

45. My Beta Esra'el informants always began to laugh when we came to talk about the Qimant. During a conversation with a priest, I heard him joke with his wife in a language which was, I learnt later, the Qimantinya dialect. Both his daughter and one of his grandsons, also present, were very surprised to hear them speak this Agäw language that they had never heard before. 
policy of endogamy; they did not have, as Quirin has aptly remarked (1977: 287), an ideology of moral superiority vis-à-vis the Amhara Christians, derived from their faith. In this they markedly differed from the Beta Esra'el.

In Qimant society there were less fundamental ideological obstacles preventing their contacts and eventual assimilation or absorption by the wider (Amhara) society. In fact, such a process was accelerated in the late 19th century, and it seems that in recent decades the Qimant religion and way of life are slowly disappearing.

The case of the Qimant shows that the Beta Esra'el were relatively unique in their response to the Amhara Christian expansion and its underlying religio-cultural model. The very fact of the original similarity of. Beta Esra'el and Qimant, with their Agäw cultural base, can also be seen as an additional argument in favour of the hypothesis that without the formative influence of the Christian dissidents of the late 14th and 15th centuries, the Judaic Beta Esra'el as we now know them would probably never have emerged.

In interpreting the mytho-legends of the Beta Esra'el as products composed in articulation with the Christian Solomonic mythical corpus, we have seen that historical events precipitating their formation took place in the early 15 th century. The politics of conquest and submission of Agäw peoples in the northern Bägemdir and Wägära regions by kings like Dawit and Yishaq decisively reshaped the politico-economic and sociocultural formations of these populations. 'Holy men' like Abba Sävra and his precursors established a model of resistance, a new religious code and thus stimulated the formation of a new collective identity for a part of the Bägemdir Agäw who transformed themselves into Beta Esra'el. In subsequent centuries, this new Judaic identity was elaborated when the Beta Esra'el were forced to defend themselves against Amhara political and cultural domination and to eke out a living as marginalized artisans, laborers or cultivators. Thus, the ethnogenesis of the Beta Esra'el, as an Ethiopian ethnic group as we now know it, seems to be of a fairly recent date.

In the description of the two phases of mytho-legendary tradition distinguished above, we have suggested that the material relating to the first phase concerning the 'holy men' (before the Solomonic period, but not conceived in that period) has to be seen in the light of the material of the second period. Only after having 'appropriated' the tenets of the Solomonic discourse-with the aid of these Christian sectarians-were the Beta Esra'el capable of formulating their ideological response to the Amhara versions of 'history'. This also may explain their adopting the Ge'ez language (for their new religious writings and prayers) instead of the Agäw. Naturally, Ge'ez (seen as part of the Christian heritage of Aksum) had become a means of domination, a symbol of power, 'manipulated' by the politico-religious elite of the Solomonic empire. The Bible, the other religious texts and commentaries, the genealogies and the chronicles of the kings, written in Ge'ez, constituted a historical charter for action, and gave the Amhara-Tigray a superiority vis-à-vis the non-literate peoples of the region. The Agäw and the proto-Beta Esra'el initially did not hold a written tradition and they lacked therefore this kind of prestigeous and unifying ideological framework. But the fascination evoked by the written sources, and the apparent force which perhaps was seen to emanate from these 'holy books', drew them also towards the contents, the ideas, expressed in them. In this way the written tradition was 'imported' by them through the Christian sectarians, and rapidly accepted. An illustrative passage concerning this is found in the earlier mentioned Gädlä Yäfqiränna-Egzi', the Christian source describing the arrival of the monk Qozemas among the 'people of the Jewish faith', or the 'heretics' (sic), we read that his hosts asked him if he could write. He then, upon their request, copied the Bible for them.

When comparing the two mytho-legendary traditions of Amhara-Tigray and Beta Esra'el, we see that the latter have, so to speak, mediated the following contradiction: the fact that they were-in their own eyes-the real Israelites who had come with Menilek from Jerusalem to instruct Ethiopia in the true faith, and at the same time were seen as a group of dispossessed and inferior pariahs and were forced to live that way. They had no economic security or political status, and were living in the midst of a society of 'apostats'. Their whole oral tradition concerning their origins is an effort to deny (the necessity of) this state of affairs. This is basically the 'message' of their mytho-legendary tradition that provides its paradigmatic structure.

The case of the Qimant demonstrates that the Beta Esra'el were not only opposed to the Christian Abyssinians, but also to 'pagan' Agäw groups. In mytho-legend 1.c, and the oral tradition cited by Kessler (1982), we note a second type of contradiction: their similarity with the Agäw (more remarkable than that of Amhara and Agäw), and in particular of course with the Qimant, who were, in Beta Esra'el eyes, certainly not 'Israelites'. Thus the emerging ethnic difference, based on political-economic inequality, was clothed with religious and ideological conceptions, which, subsisting up to the 20th century, contributed to the transformation of the Beta Esra'el into 'Ethiopian Jews'.

\section{The mythical operation.}

On the basis of the specific historical conditions of Northwest Ethiopian society, profoundly marked (since the 9 th century) by the growing influence 
of Monophysite Orthodox Christianity, the 'sacred narratives' of both the dominant and the peripheral peoples took shape. We have found a combination of biblical religious mythical material with local traditions and legends, stamped by dramatic political events of the period. It may have been obvious that a neat distinction between 'myths' and 'legends' could not be kept up. The aspect of 'charter', which characterized certain central narratives of both Amhara-Tigray and Beta Esra'el has made them mingle. This is the reason for using the term 'mytho-legend', in the sense of collective representations in narrative form, functionalist in nature, and explaining the origins and existence of certain groups in a divine/supernatural framework giving them a 'mission' or a raison d'être.

We have also been able to conclude that the 'mythical operation', that is the structuration of conceptual relations and representations in the narratives of the two main groups studied, has proceeded according to a fairly constant schema or paradigm. Concerning the Beta Esra'el, one can see that in the narratives referring to the first period a structure of parrallel opposition is always present, recurrent in all versions of type 1. The Beta Esra'el are represented as the 'loyalists', who remained attached to the real Israelite faith while the Amhara-Tigray ancestors are designated as the renegades who have lost it, and with it, God's grace. The type 2 narratives show a different elaboration: they emphasize the direct, unmediated link with the Israelites of the Pentateuch (Torah, 'Orit), shortly after the Exodus from Egypt. Inspired by the Biblical story, these versions (all conceived more recently than those of type 1) express a different kind of opposition to the Amhara-Tigray. They convey the message that the Beta Esra'el, capable of tracing their origins even back to the momen of genesis of the ancient Israelites, cannot but be considered the real ancestral Israelites in Ethiopia. They state that they have come well before the Amhara-Tigray, who, at most, refer to the myths of the Kibrä Nägäst. Nevertheless, these type 2 narratives seem indeed to have been derived from those of type 1, which, for the Beta Esra'el, expressed the problem of their ancestry by their character of parallelism to the Amhara tradition.

The second phase of the mytho-legendary tradition evinces a deflection of the Solomonic-style and pseudo-biblical myths by way of the creative appropriation of the Christian-inspired monastic model and its religious tenets. ${ }^{46}$ This appropriation is all the more understandable in view of the lack of a written tradition (no Hebrew, no Ge'ez) among the protoBeta Esra'el of that time. But again there is a parallelism with the

46. It should be emphasized that this oral tradition of the monks and holy men or sages of the Beta Esra'el deserves more intensive research before it is too late. work in this respect. dominant 'superstructure' of the Christians. Abba Sävra, the saint of mysterious origin, (re)forms the ideology and religious practice of the Beta Esra'el in disarray and institutes the paradigmatic theme of opposition (orthodoxy/apostasy, or real faith/renegade faith; political submission/rebellion; incorporation/autonomy, etc.), a theme elaborated also in the ritual domain (purity/pollution, in the sphere of marriage, physical contact and food). Probably a closer analysis of the internal logic of the (system of) religious customs and underlying ideas of the Beta Esra'el faith (concerning God, sabbath, the priests, the sacrifices, the purity rules, etc.) would have been instructive, but it is now too late to carry this out in the original setting.

In describing the difference between 'myths' and the 'mytho-legends' we have stressed the way according to which 'history'-as reflection of (the meaning of) certain events, persons, or chronology-is allowed to enter them. Mytho-legendary narratives, as elements of a historical discourse, can appear as charters. But we may note that for the same reasontheir historical 'susceptibility' - the mytho-legends risk losing their entire foundation or ideological significance in conditions of rapid social or political change. This is what has, of course, been happening with the Solomonic narratives of the Abyssinian Christians (e.g., the Menilek myth) after the Ethiopian revolution of 1974: in the public domain and in historiography, they have lost an importance they might have had. In the case of the Beta Esra'el, a reverse development has occurred with regard to the (anti-)Solomonic stories concerning the first period, especially as a result of the growing identification with Western or Israeli Judaism. In Israel, these stories (of their descent from contemporaries of Solomon and the Queen of Sheba) are referred to as narratives approximately explaining their origin and their migration to Ethiopian shores. But the second tradition (concerning the holy men like Abba Sävra), which ironically was first presented by old Beta Esra'el priests as a very important tradition, is devaluated. From the religious-Jewish point of view this is indeed an 'embarrassing' tradition, which was/is believed to cast doubt on the origin and Jewish identity of the Beta Esra'el. However, a scientific approach, as we have aspired to follow here, arrives at other conclusions, and-for other reasons-has neither the capacity nor the need to question the original and remarkable Jewish identity of today Beta Esra'el, which has led them to embark upon their massive emigration to Israel.

\section{Future research}

The argument of this study cannot be but part of a future comprehensive explanation of Beta Esra'el historical development, which should combine all crucial literary, archaeological, ethnomusicological and historical findings to date. Obviously, our conclusions concerning the relatively recent 
'ethnogenesis' of the Beta Esra'el and their shared discourse with the Amhara-Tigray Christians are tentative, like any scientifically-oriented hypothesis. But it will be difficult if not unacceptable to fall back on the traditional point of view, unquestioningly accepting the non-Ethiopian origins of the Beta Esra'el seen as traversing time and space like an impermeable Jewish capsule.

It remains for us to express hope that research on this group continues and that it will, among others subjects, deal with the critical study of the Gädlat of the 14th up to the 16th century (and the search for new Gädlat in Ethiopia); study the period of the political-religious reforms of the Aksumite king Gäbrä Mäsqäl (9th century); produce a more detailed study of the historical-cultural traditions of Ethiopian ethnic groups (Christian and 'pagan' or tribal) and their interaction, especially from the 13th up to the 15th century (cf. the fascinating studies of Taddesse Tamrat); make the complete recording and comparative study of the remaining oral and written traditions of the Beta Esra'el in Israel; study the details of North Ethiopian medieval history (for instance, the period of the wars with the Islamic armies of Ahmed Gragn and their consequences on the Beta Esra'el, and the effects of the contacts between Yemen and Ethiopia); focus on the archaeology of ancient holy places and other sites in Northern Ethiopia, for example, the abandoned churches or monasteries or the $a m b a s^{47}$ of the Beta Esra'el region in Simien.

The various research projects in progress or in preparation (especially in archaeology, now that the civil war in Northern Ethiopia seems to have ended) will hopefully yield new data to refute or confirm the conclusions of the present study.

Katholieke Universiteit,

Nijmegen, 1991.

47. The ambas are the flat-topped mountain fortresses in Simien where the Beta Esra'el defended themselves against the Abyssinian armies. The location of the Beta Esra'el ambas is not known exactly, although one often reads about an 'Amba Ayhud', an 'Amba Redai', and others. Some maps of 19th- or early 20th-century European travellers sometimes show an 'Amba Fälassa'. For an example, see the Italian map 'Agordat' of the Istituto geografico militare, 18981900 (edizione 1934 , qait near the Amba Adi Ero and Amba Chercher.

BIBLIOGRAPHY

Abbadie, A. d'

1845a 'Sur les Falachas ou Juifs d'Abyssinie', Bulletin de la Société de Géographie IV (3) : 43-47, 65-74.

1845b 'Les Falachas ou Juifs Éthiopiens', Revue de l'Orient VII: 222-235.

1851 'Réponses des Falachas dits Juifs d'Abyssinie aux questions faites par M.Luzzato . . ', Archives israélites XII: 179-185, 234-240, 259-269.

AbBinK, J.

1984a 'The Changing Identity of Ethiopian Immigrants (Falashas) in Israel', $A n$ thropological Quarterly XLVII (3): 139-154.

1984b The Falashas in Ethiopia and Israel: The Problem of Ethnic Assimilation (Nijmegen: Instituut voor Culturele en Sociale Antropologie).

1987 "A Socio-Structural Analysis of the Beta Israel as an "Infamous Group" in Traditional Ethiopia', Sociologus XXXVII (2): 140-154.

Aešcoly, A.Z.

1962 'Notices sur les Falacha ou Juifs d'Abyssinie, d'après le "Journal de Voyage" d'Antoine d'Abbadie', Cahiers d'Études africaines II (1), 5: 84-147.

Ashrenazi, M.

1988 'Political Organization and Resources among Ethiopian immigrants', Social Science Information XXVII: 371-389.

Ben Dor, S.

1985 'Meqomot haKedoshim shel Yehudé-Etiopia', Pe'amim XXII: 32-52.

Bezold, C.

1905 'Kebra Nagast. Die Herrlichkeit der Könige', Abhandlungen der Königlichen Bayerischen Akademie der Wissenschaften (München), XXIII (I): I-LXII, 1-160.

BRUCE, J.

1830-1832 Voyage aux Sources du Nil en Nubie et en Abyssinie (1768-1772) (Paris: E. Lecointe), 9 vol.

Budge, E. A. W.

1928 A History of Ethiopia. Nubia and Abyssinia (London: Methuen), 2 vol.

CARmoly, E., ed.

1847 Itinéraires de la Terre Sainte, des XIII' $, X I V^{e}, X V^{e}, X V I^{e}$ et $X V I I^{e}$ siècles (Bruxelles: A. Vandale). 
Conti Rossini, C.

1919-1920 'Appunti di storia e letteratura Falascia', Rivista degli Studi orientali VIII: 563-610.

Doléve-Gandelman, $T$.

1989 '"Ulpan" is not Berlitz: Adult Education and the Ethiopian Jews in Israel' Social Science Information XXVIII: 121-143.

Dundes, A., ed.

1984 Sacred Narrative. Readings in the Theory of Myth (Berkeley-Los Angeles - London: University of California Press).

FlAD, J. M.

1869 Kurze Schilderung der bisher fast unbekannten abessinischen Juden (Falascha) (Kornthal: Selbstverlag).

Friedmann, D. \& Santamaria, U.

1990 'Identity and Change: The Example of the Falashas, between Assimilation in Ethiopia and Integration in Israel' Dialectical Anthropology XV: 56-73.

GAMst, F. C.

1969 The Qemant: A Pagan-Hebraic Peasantry of Ethiopia (New York: Holt, Rinehart \& Winston).

Getatchew Haile

1982 'A New Look at Some Dates of Early Ethiopian History', Le Muséon XCV (3-4): 311-322.

Gobat, S.

1834 Journal of a Three Years' Residence in Abyssinia (London: Hatchard).

Goldberg, A. I. \& Kirschenbaum, A.

1989 'Black Newcomers to Israel: Contact Situations and Social Distance', Sociology and Social Research LXIV (1): 52-57.

HABERLAND, E.

1965 Untersuchungen zum äthiopischen Königtum (Wiesbaden: Steiner Verlag).

HALÉVY, J.

1873 'Essay sur la langue Agau, le dialecte des Falachas', Actes de la Société philologique III (5) : 151-188.

1877a 'Travels in Abyssinia', in A. Lowy, ed., Miscellany of Hebrew Literature, vol. II (London: Trubner): 177-256.

1877b Prières des Falachas ou Juifs d'Abyssinie (Paris: J. Baer).

Hess, R. L.

1969 'An Outline of Falasha History', in Proceedings of the Third International Conference on Ethiopian Studies, Addis Ababa 1966, vol.I (Addis Ababa: Institute of Ethiopian Studies, Haile Selassie I University): 99-112.

KAPLAN, S.

1982 'Ezana's Conversion Reconsidered', Journal of Religion in Africa XIII (2): $101-109$.
1984 The Monastic Holy Man and the Christianization of Early Solomonic Ethiopia (Stuttgart: Steiner Verlag).

1985a 'The Falasha and the Stephanite', Bulletin of the School of Oriental and African Studies XLVIII (2): 278-282.

1985b 'The Beta Israel (Falasha) in the Ethiopian Context', Israel Social Science Research III (1-2): 9-20.

1987 'Te'ezaza Sanbat: A Beta Israel Work Reconsidered', in S. SHAKed, ed., Gilgul. Essays on Transformation, Revolution and Permanence in the History of Religions (Leiden: E. J. Brill): 107-124.

1988 'The Beta Israel and the Rabbinate: Law, Ritual and Politics', Social Science Information VII: $357-370$.

KAPLAN, S. \& Ben Dor, S., eds.

1987 Ethiopian Jewry. An Annotated Bibliography (Jerusalem: Ben Zvi Institute).

Kessler, D.

1982 The Falashas. The Forgotten Jews of Ethiopia (London: George Allen \& Unwin).

KoBishCHANOv, Y.M.

1979 Axum (University Park-London: Pennsylvania State University Press).

KREMPEL, V.

1972 Die soziale und wirtschaftliche Stellung der Falascha in der christlichamharischen Gesellschaft Nordwest Äthiopiens (Berlin: Freie Universität).

LEACH, E. R.

1969 Genesis as Myth (London: Jonathan Cape).

LeACH, E. R. \& AycocK, A.

1983 Structuralist Interpretations of Biblical Myth (Cambridge: Cambridge University Press).

LesLau, W.

1957 Coutumes et Croyances des Falacha ou Juifs d'Abyssinie (Paris: Institut d'Ethnologie).

1975 'Taamrat Emmanuel's Notes of Falasha Monks and Holy Places', in Salo Wittmayer Baron Jubilee Volume (New York-Jerusalem: American Academy for Jewish Research): 623-637.

LeVINE, D. N.

1974 Greater Ethiopia. The Evolution of a Multiethnic Society (Chicago-London: University of Chicago Press).

1975 'Menilek and Oedipus: Further Observations on the Ethiopian National Epic', in H. G. MARcus, ed., Proceedings of the First United States Conference on Ethiopian Studies 1973, (East Lansing: Michigan State University, African Studies Center): 11-23.

Luzzato, $\mathbf{P}$.

1851 'Mémoire sur les Juifs d'Abyssinie ou Falachas', Archives israélites XII: 428-435, 488-496, 548-555, 570-574. 
1852 'Mémoire sur les Juifs . . ., Archives israélites XIII: 150-154, 215-221, 283-288, 343-346, 471-475, 533-537, 647-656.

1853 'Mémoire sur les Juifs . . ', Archives israélites XIV: 97-103, 165-171, 466-473, 519-527.

1854 'Mémoire sur les Juifs . . ', Archives israélites XV: 344-353, 642-653.

PARFITT, T.

1985 Operation Moses. The Story of the Exodus of the Falasha Jews from Ethiopia, (London: Weidenfeld \& Nicholson).

Perruchon, J. 1889 'Histoire des guerres d'Amda Syon', Journal asiatique VIII (14) : 271-363,
$381-493$.

Quirin, J. A.

1977 The Beta Israel (Falasha) in Ethiopian History: Caste Formation and Culture Change, 1270-1868 (Minneapolis: University of Minnesota).

1979 'The Process of Caste Formation in Ethiopia: A Study of the Beta Israel (Felasha), 1270-1868', International Journal of African Historical Studies XI (2): $235-258$

RAPOPORT, L. A.

1986 Redemption Song: The Story of Operation Moses (New York: Harcourt, Brace, Jovanovich).

REY, C. F.

1935 The Real Abyssinia (London: Seeley Service).

Rodinson, M.

1964 'Sur la question des “influences juives" en Éthiopie', Journal of Semitic Studies IX (1): 11-19.

SAFRAN, C.

1987 Secret Exodus: The Untold Story of how Operation Moses saved the Lost Tribe of Ethiopian Jews (New York: Prentice Hall).

SCHOENBERGER, M.

1975 The Falashas of Ethiopia: An Ethnographic Study (Cambridge: Clare Hall, Cambridge University).

Sergew Hable Selassie

1972a 'The Problem of Gudit', Journal of Ethiopian Studies X (1): 113-124.

1972b Ancient and Medieval Ethiopian History to 1270 (Addis Ababa: United Printers).

SHAHID, I.

1976 'The Kebra Nagast in the Light of Recent Research', Le Muséon LXXXIX (1-2): 133-178.

Shelemay, K. K. 1977 The Liturgical Music of the Falashas of Ethiopia (Ann Arbor: University of
Michigan).
1978 'A Quarter-Century in the Life of a Falasha Prayer', Yearbook of the International Folk Music Council X: 83-103.

1980 “" "Historical Ethnomusicology”: Reconstructing Falasha Liturgical History', Ethnomusicology LXXX (2): 233-258.

1986 Music, Ritual and Falasha History (East Lansing: Michigan State University, African Studies Center)

SPENCER, M.

1979 'Structural Analysis and the Queen of Sheba', in R. L. Hess, ed., Proceedings of the Sixth International Conference on Ethiopian Studies, Session B, Chicago 1978 (Chicago: University of Illinois at Chicago Circle): 343-358.

TADDESSE TAMRAT

1972 Church and State in Ethiopia, 1270-1527 (Oxford: Clarendon Press).

1988a 'Processes of Ethnic Interaction and Integration in Ethiopian History: The Case of the Agaw', Journal of African History XXIX (1): 5-18.

1988b 'Ethnic Interaction and Integration in Ethiopian History: The Case of the Gafat', Journal of Ethiopian Studies XXI: 121-154.

Trevisan Semi, E.

1987 Allo specchio dei Falascià. Ebrei ed Etnologi durante il Colonialismo fascista (Firenze: Editrice La Giuntina).

ULLENDORFF, E.

1968 Ethiopia and the Bible (London: Oxford University Press).

WAJNBERG, I., ed.

1936 Das Leben des Hl. Jafqerana 'Egzi' (Rome: Pontificum Institutem Orientalium Studiorum) ("Orientalia Christiana Analecta" 106).

Y'ARI, A., ed.

1971 Yiggarot Eretz Yisrael (Tel Aviv). 